\title{
The Remains from Late Antiquity and the East Roman Periods and Their Location within the Lydian City of Philadelphia: New Comments
}

\author{
Lydia'daki Philadelphia'da Geç Antik ve Doğu Roma Dönemi Kalıntıları ve Bu \\ Kalıntıların Kent İçindeki Yayılımları: Yeni Yorumlar
}

\section{Orçun ERDOĞAN*}

\begin{abstract}
Philadelphia, mentioned amongst the seven churches of Asia in the Bible, was one of the cities from which Christianity began to spread. It was also the last metropolis of the ecclesiastical province of Lydia and, with the exception of the empire of Trebizond, was the last East Roman city in Anatolia to fall to the Turks. This study investigates the Late Antique and East Roman remains and their location within the ancient city centre of Philadelphia/Alaşehir in the lights of new observations. Unlike many Hellenistic-Roman long settled ancient cities in Anatolia that went into decline, or which were abandoned after Late Antiquity, Philadelphia was inhabited until about the last 60 years of East Roman Empire. Only a small number of remains from Late Antiquity and the East Roman period remain extant and unfortunately almost all of them are to a large extent damaged. One may nevertheless summarize the evidence as it follows: The remains are in three section of the city centre of Alaşehir: Gavurtepe Mound, Toptepe and the walled precinct. No traces of a settlement from the period in question have been found in the earliest settlement of Philadelphia, Gavurtepe, except for the burials. Similarly a number of burials have been uncovored in Toptepe as well as other remains which also indicate a settlement inhabited in Late Antiquity and the East Roman period. The walled precinct and Toptepe was clearly the city centre of Philadelphia in the Roman Imperial Period as in Late Antiquity and in the East Roman period.
\end{abstract}

Keywords: Philadelphia, the Church of St. John the Theologian, City Walls, Ancient Sewers, Saw-Tooth

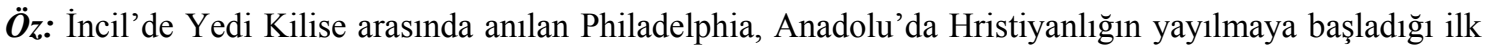
kentlerden biridir. Lydia kilise bölgesinin son metropolisi olan kent, aynı zamanda, Trabzon Rum Devleti dışında Anadolu'da Türklerin eline geçen son Doğu Roma kalesidir. Bu çalışmada, Alaşehir merkezindeki Geç Antik-Doğu Roma dönemlerine ait kalıntılar ve bu kalıntıların eski kent içindeki dağılımları yeni tespitler 1şığında incelenmektedir. Philadelphia, Anadolu'da geç antikçağ sonrası çoğunlukla gerilemiş ya da terkedilmiş birçok Hellenistik-Roma kökenli antik kentlerden farklı olarak Doğu Roma'nın yaklaşık son 60 yılına kadar iskân görmüştür. Yerleşim, Alaşehir kent merkezinin üç kısmına yayılmaktadır: Gavurtepe Höyüğü, Toptepe ve Suriçi. Gavurtepe Höyüğü’nde gerçekleştirilen kazı çalışmalarında, incelediğimiz döneme ait basit mezar kalıntıları dışında herhangi bir yerleşim katmanı henüz tespit edilememiştir. Benzer şekilde, Tiyatro ve Tapınak gibi Roma dönemi eserlerinin bulunduğu Toptepe'de yapılan kazılarda da aynı dönemlere tarihlenen birçok basit mezar ortaya çıkartılmıştır. Ancak burada aynı zamanda geç antikçağ ve Doğu Roma dönemleri boyunca yerleşime işaret eden, azımsanmayacak derecede kalıntı saptanmıştır. Suriçi bölgesi, belli ki bir zamanlar en azından Toptepe ile birlikte Roma İmparatorluk dönemi şehir merkezini oluşturuyordu.

Anahtar sözcükler: Alaşehir, Teolog Aziz Ioannes Kilisesi, Kent Suru, Antik Kanallar, Testere Dişi

\footnotetext{
* Arş. Gör., Akdeniz Üniversitesi, Edebiyat Fakültesi, Sanat Tarihi Böl., Antalya. orcunerdogan@akdeniz.edu.tr
} 


\section{A Brief History}

Philadelphia, today known as Alaşehir, is about forty-five kilometers southeast of Sardis. It lies in the Valley of Kogamos at the foot of the Tmolos (modern Bozdağ). Even though the earliest history of the city dates from the Early Bronze Age (Meriç 1986, 261; Meriç 1988, 157-158), the settlement called Philadelphia was founded by Attalos II Philadelphos in the second century B.C. (The city may have been founded as early as Seleukos I (358 BC-281 B.C). See Onur 2013, 37 fn. 105. See also Thonemann 2011, 174). The city was annexed by the Romans in 133 B.C. with Attalos III's bequest (Arslan 2007, 68 vd.) and became one of the cities of the Roman Province of Asia through which the Imperial Post Road passed (Ramsay 1904, 315). In 17 A.D. an earthquake damaged the city and it was reconstructed immediately afterwards, apparently under the authority of emperor Tiberius (Ramsay 1904, 316; Ceylan, 2004, 33. For the accounts of Strabon see especially on Geographica XIII. 4. 10). Pliny recounts that Philadelphia was in the admistrative district (conventus) of Sardis during the Roman Imperial Period (Onur 2013, 37 fn. 105). Its ongoing importance is attested by its title Neocorate which enabled Philadelphia from reign of Caracalla to Trajan Decius to repeatedly celebrate Imperial Festivals (Burrel 2004, 396-397).

The provincial structure of the empire was revised in the reign of Diocletian, and Philadelphia became one of the cities of the province of Lydia in Late Antiquity, again under the juristiction of the capital city Sardis which also afterwards was to become the metropolis of the ecclesiastical province of Lydia until the XIV ${ }^{\text {th }}$ century (Foss 1976, 4). During the Crisis of the Third Century, shortly before the reign of Diocletian, both the literary and archaeological evidence indicates Gothic raids on some of the neighbouring cities in Asia and Lydia, and clearly these Gothic raids at least threated Philadelphia (Mitchell 1993, 235-236).

A written source which records a meeting of armies in Philadelphia in the reign of Theodosios, demonstrates that by the end of the $\mathrm{IV}^{\text {th }}$ century, the city retained its distinction as one of the major cities through which the Imperial Main Road passed (Zosimos recounts that in the time of Theodosios, barbarian soldiers met some of the soldiers from Egypt in Philadelphia where they were recruited into their legions. See Zosimos IV. 30. see Ridley 1990).

As late as the $\mathrm{VI}^{\text {th }}$ century Philadelphia was still renowned for its festivals and temples and was called the "little Athens", presumably as was the case for other Lydian cities and neighbouring provinces (Foss 1991, 1648; Onur 2013, 51-52. For a study involving the fate of paganism in Philadelphia and partly in Lydia see Erdoğan 2014, 176). However Ioannes Lydos reports the suffering of the city and probably also its countryside, due to the cruel attitude and exactions of John Maxilloplumacius and his tax collectors which caused Philadelphia in the $\mathrm{VI}^{\text {th }}$ century to be "stripped of its money and people and left it without the resources to recover" (For other events in Philadelphia in the $\mathrm{VI}^{\text {th }}$ century see also, Foss 1976, 11-12; Kelly 2004, 174).

After the account provided by Ioannes Lydos, both the literary and archaeological evidence for the later history of Philadelphia is lacking until the $\mathrm{XI}^{\text {th }}$ century. After the Crisis of the Third Century, a second crisis emerged as a consequence of the invasions of both Persians and Muslims through certain parts of Anatolia in the VII ${ }^{\text {th }}$ century. Whether or not these invasions affected Philadelphia is uncertain, while the archaeological remains in the neighbouring city Sardis provides much evidence that points to a destruction level in the first half of the VII ${ }^{\text {th }}$ century by the Persians and probably subsequently by the Arab Muslim led forces (Zanten 1975, 36; Foss 1976, 82-85). Theophanes recounts that the expeditions of the Muslims under the leadership of Abimelech still threatened Lydia as late as 798/9 (Theophanes 474, see Turtledove 1982). One can at least glean from this fragmentary evidence that Philadelphia was under threat 
during the $\mathrm{VII}^{\text {th }}$ and VIII ${ }^{\text {th }}$ centuries and was perhaps to some extent damaged, while it continued to retain its significance.

In the VII ${ }^{\text {th }}$ century, when Anatolia was divided into four themes, military units, Philadelphia was in the Anatolikon Theme. Subsequently, with the division of the first themes into smaller units, presumably in the first half of the VIII ${ }^{\text {th }}$ century, it became one of the cities of the Thrakesion Theme (Kazhdan 1991, 2034-2035).

After a couple of centuries, relatively more comprehensive information concerning the city comes with the penetration of the Seljuk Turks into Anatolia. The chronicles of the $\mathrm{XI}^{\text {th }}$ and ensuing centuries have recorded many battles and assaults on Philadelphia (Anna Komnena Alexiad, XII. 5; XIV. 1; see also Umar 1996; Ioannes Kinnamos, Historia, I. 6; IV. 195; see Demirkent 2001; Niketas Khoniates, Historia, 522-523, 539, see Demirkent 2006; Mikhael Doukas, I. 4. see Umar 2008). The city became the capital of the Thrakesion Theme by the middle of the XII ${ }^{\text {th }}$ century and was the base for military expeditions to the east due to its location on the frontier with the Seljuk Turks (Foss 1976, 72; 1991, 1648). During this period, Philadelphia was besieged and taken and retaken many times, however it remained the last independent East Roman city in western Anatolia, as well as the metropolis of the ecclesiastical province of Lydia (The metropolitan of Philadelphia, Makarios Khrysokephalos, signed the synodal decrees with the title "Metropolitan of Philadelphia, Hypertimus and Exarch of all Lydia and universal Judge of the Romans", as late as the middle of the XIV ${ }^{\text {th }}$ century and became the metropolis of Lydia after the Metropolitan See of Sardis was dissolved in 1369. See Meinardus 1974, 81; Foss 1976, 88- 89. For the text of the synodic act (1369) to the Bishop of Philadelphia see Foss 1976, 127- 128) until its final capture in 1390/91 by Sultan Bayezid I (Vryonis 1971, 140, 414; Mikhael Doukas I. 4. see Umar 2008).

Literary evidence also provides several references to the ecclesiastics of the city and shows that its bishops undertook many missions concerning political and religious affairs during the recorded history of Philadelphia. Based upon the accounts of George Akropolites, the works of some ecclessiastics of the city and the list of Le Quien, a general, albeit incomplete list is as follows: Bishop Hetimasius at the Council of Nicaea (325); Kyriakos at the Council of Philippopolis (344); Bishop Theodosios at the Council of Seleukeia (359); Theophanes at the Council of Ephesos (431); Asianos (458); Eustathios (518); John at the Council of Constantinople (680); Stephanos at Nicaea (787); Michael under Leo the Armenian; Phokas, metropolitan of Philadelphia in the XIII ${ }^{\text {th }}$ century; Theoleptos, metropolitan of Philadelphia from the the end of $\mathrm{XIII}^{\text {th }}$ century through the early $\mathrm{XIV}^{\text {th }}$ century; Manuel Gabalas, who took several offices such as anagnostes, deacon, protonotarios and khartophylaks in the early $\mathrm{XIV}^{\text {th }}$ century in Philadelphia; Makarios Khrysokephalos, metropolitan of Philadelphia (1336-1382) (http://www.newadvent. org/cathen/11793a.htm; Talbot 1991b, 2056-2057; Browning 1992, 27; Sinkewicz 1992, 1-26; Jonsson 2005, 385-386; George Akropolites 50, see Macrides 2007).

\section{The City Walls}

Strabon was the first to record the walls of Philadelphia (XII. 8. 18), although whether or not he referred to the city walls enclosing the city of Alaşehir is unclear.

After a long period of silence, literary evidence for the years following the Turkish expansion in Anatolia once again provides some information about the operational existence of the city walls, but is lacking any detailed description (Anna Komnena, Alexiad, XIV. 1).

Structural descriptions of the walls seems to have been made as early as the XVII ${ }^{\text {th }}$ century by Evliya Çelebi who noted that the city walls were in ruins and had five gates (Evliya Çelebi IX. 31; see also Koz 2013). Other travellers in subsequent centuries mentioned the walls, 
providing more detail, information on the building materials employed, the round towers and the large gaps in the fortifications (Chandler 1971, 197; Arundell 1828, 167; Hartley 1831, 304; Elliott 1838, 87; Allom 1839, 72; Hamilton 1842, 374; Texier 2002, 83- 84). It seems after the final Ottoman conquest of the city in the late XIV ${ }^{\text {th }}$ century, the walls must have fallen into disuse and were subsequently neglected.

A relatively more comprehensive observation made of these structures by Curtius in the early 1870 's is significant as his article also includes a plan of the city walls (Curtius 1872, 9395 and Tafel VIII). The first exhaustive study that focused directly upon the walls was published in 1984 (Pralong 1984, 101-125) and a number of archaeological excavations were conducted at the East Gate in 1987 and 1988 by Recep Meriç $(1988,159 ; 1989,181)$.

\section{General Characteristics}

The city wall of Philadelphia is roughly rectangular in plan, but there are some re-entrant angles particularly in the east and south sections, while the other sections of the traces are for the most part straight (Fig. 1). Today it is surrounded by Süleyman Demirel Caddesi to the north; Dumlupinar Caddesi to the east and Ziya Gökalp Caddesi to the west. The south section of the city wall must have partly enclosed Toptepe. The larger part of the city wall, except for the northeast section, can hardly be seen amongst the apartment buildings, houses and shops: in some cases the traces constitute the wall of a courtyard or the main wall of residences and shops. There are also many gaps in the fortification and the larger quantity of the surviving wall remains, unsurprisingly lack the facing stones. It has been argued that the city wall had a double and even a triple defence system according to some researchers and travellers but no specific layout or location has been given; and today, neither evidence for a triple nor double defence systems could be found (Allom 1839, 72; Curtius 1872, 94; Zanten 1975, 41- 42). The city wall at Philadelphia was also protected by towers, presumably positioned about every 70 to 90 metres (Curtius 1872, 94-95). However, today only four of these structures can be identified with certainty as towers, two of which flank the East gate (Zanten 1975 reported that there had been traces of at least 12 towers, most of these on the north and east sides. See Zanten 1975, 42).

Although the city walls of Philadelphia are not sufficiently well preserved, a few wall remains enable us to establish some basic characteristics concerning the construction techniques and materials employed. These walls are about 3 meters thick and 7 meters high, consisting of a core of mortared rubble with a facing of fieldstones. The facing generally contains courses of large and smaller stones with the alternation of levelling courses of flat stones. Gaps between the stones are filled by small stones, and rarely, by brick fragments. However the facing courses are mostly unclear, probably due to the erosion that damaged the mortar. While such facing arrangements can be observed in every part of the remains, the use of field stones with the alternation of brick for facing on some towers is remarkable. Apart from the roughly cut fieldstones, almost no spolia were employed in the facing of the walls. There are also regular courses of holes in many parts of the city wall which can be traced on both faces of the wall, in which there have been timbers, which is an evidence of a bonding system and seismic shock absorber (these timbers would also have projected to support scaffolding for the repair and replastering of the walls). As for the gates, a small number have reached the present day. As to if the city wall had a battlement structure, this is today uncertain, although some traces were noted some four decades ago (Zanten 1975, 42), but no evidence for this remains in-situ today.

\section{Additional Remarks}

More detailed information, concerning in particular the gates and the towers obtained from excavations, surveys and recent research is briefly examined below. 


\section{East Section}

Nine fragments of walls, three towers, in addition to a gate (East Gate) have been identified. The northeast part (from 1 to 4 ) is better preserved than the rest of the section (Fig. 2).

There is a gate (2) located near the north-eastern corner of the city wall. One can still see it with its upper wall and flanking towers projecting eastward on both sides.

The East Gate consists of a barrel vaulted passage which is about $2.65 \mathrm{~m}$ high and $5.11 \mathrm{~m}$ wide. Only the mortared rubble of the vault is extant today. But the west side of the passage was once faced by a brick arch (Zanten 1975, 41). The east side of the gate was blocked with spolia blocks and rubble stones. In the excavation conducted in front of the east face of the gate, a number of arrowheads and spearheads stuck in the skeletons of bodies were recovered (Meriç $1988,159 ; 1989,181)$.

The North Tower adjacent to the East Gate is rectangular in plan. Its inner part is full of debris. All of the facing stones, except for those badly preserved on the southern face, have crumbled and today one mostly sees only the mortared rubble core.

Another tower to the south of the gate is semicircular in plan with a radius of $7.70 \mathrm{~m}$ and is better preserved, compared to the other. Its interior is also full of debris. Only the northern facing of the wall is extant, composed of rows of field stones alternating with courses of brick ranging from 2 to 6 . Brick fragments were also employed to fill the gaps between the rows of stones. The south quarter of the tower is not preserved and there is a side road passing through its former position.

The third tower is located at the southeastern corner of wall number 3. It projected eastward like the other two towers and has a diameter of $8.60 \mathrm{~m}$. The north part is faced with coursed field stones, with the gaps between the stones filled with fragments of brick and smaller stones.

If the city wall once had a battlement is uncertain. The traces of two stairways built into the west side of the upper part of the walls near to the northeastern gate were found in the 1970's and it is suggested that these staircases ascended to parapets that would have been constructed of brick or timber (Zanten 1975, 42. The inhabitants of Philadelphia could find their way up onto the walls somehow in the XII ${ }^{\text {th }}$ century, probably employing stairs or ladders. See Anna Komnena, Alexiad, XIV. 1).

The wall remains in the southern part of the east section (from 5 to 9) are the least well preserved and most can barely be determined within the courtyards of the houses. Wall number 7, with its structure distinct from the other walls, probably formed a part of a tower.

\section{North Section}

There are 9 fragments of walls, 2 small postern gates and a tower. In particular the north-eastern part of the section, not blocked by any buildings (from 10 to 11 ), has been subjected to a better investigation of the walls and of the two gates (Fig. 3).

At the north-eastern corner of the fortification there is a tower with a diameter of $11 \mathrm{~m}$. The facing is similar to that of the third tower.

There are two postern gates, close to each other along wall number 10 which is connected to the north-eastern corner. Only the northern faces of the gates can be seen today as there is a terrace in the southern part (inside) wall numbers 10 to 11 . The large part of the doorway of the postern gate 1 is covered in debris and earth. What may be seen today is a part of a jamb with a fragment of column surmounted by a lintel and the remains of the springing of the brick arch above it. About seven metres further to the west is postern gate 2 which was blocked with mortared rubble, a precaution made in a similar manner to that of the Eastern Gate. Its round 
brick arch remains standing.

In the rest of the section (from number 12 onwards) the wall remains can barely be traced between the shops and dwellings. Nevertheless, some can still be observed part-way along the street (Kale Arkası Çıkmaz Sokak) and from a careful look from long distance. There is no difference in the construction method or the facing employed from the other remains. No trace of a tower or a gate has been identified. Two points deserve mention: firstly, the wall at the westernmost of the southern face of number 15, is faced with three spolia blocks. Secondly, a gate, called the Dombay Kapl, the location of which R. Akınc1 relates and, according to this localisation, this gate can at least be said to have been in the northern section of the city walls (This section is also said to be called the Vicinity of Dombay Kap1. Akınc1 1949, 99; Doğan 2002, 11; Ceylan 2004, 136).

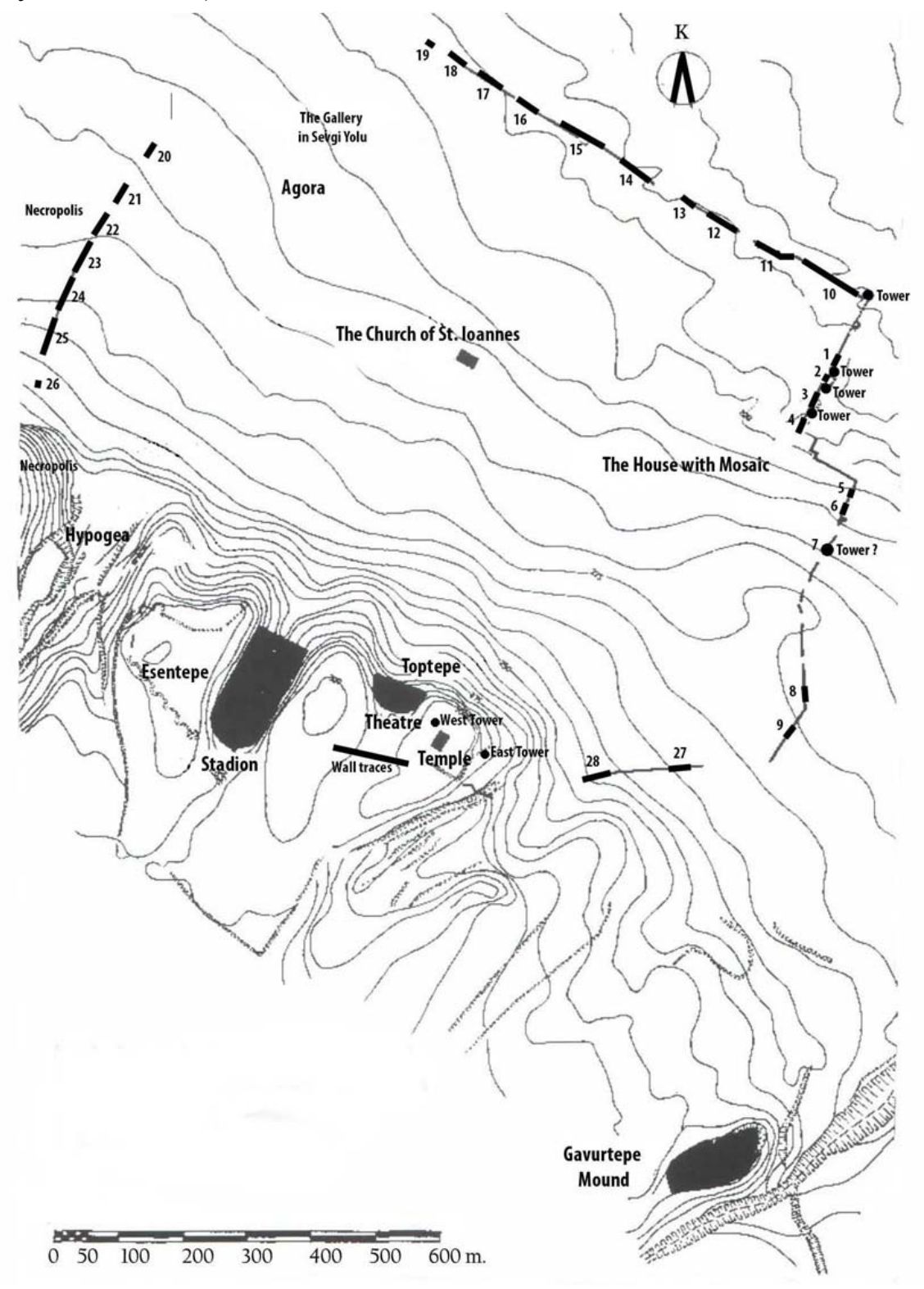

Fig. 1. Philadelphia, plan. Meriç 1986 (plan 1) and Karakaya 1995/1996 (şekil 1) (modified) 


\section{West Section}

All of the remains are located at the southwestern half of the section (from 20 to 26) (The large part of the remnants lie within today's Sakarya Mahallesi) where 9 fragmentary remains of walls and a gate have been identified. However, investigating the remains amidst the dense growth of new apartment blocks is today more difficult than ever before (Fig. 4).

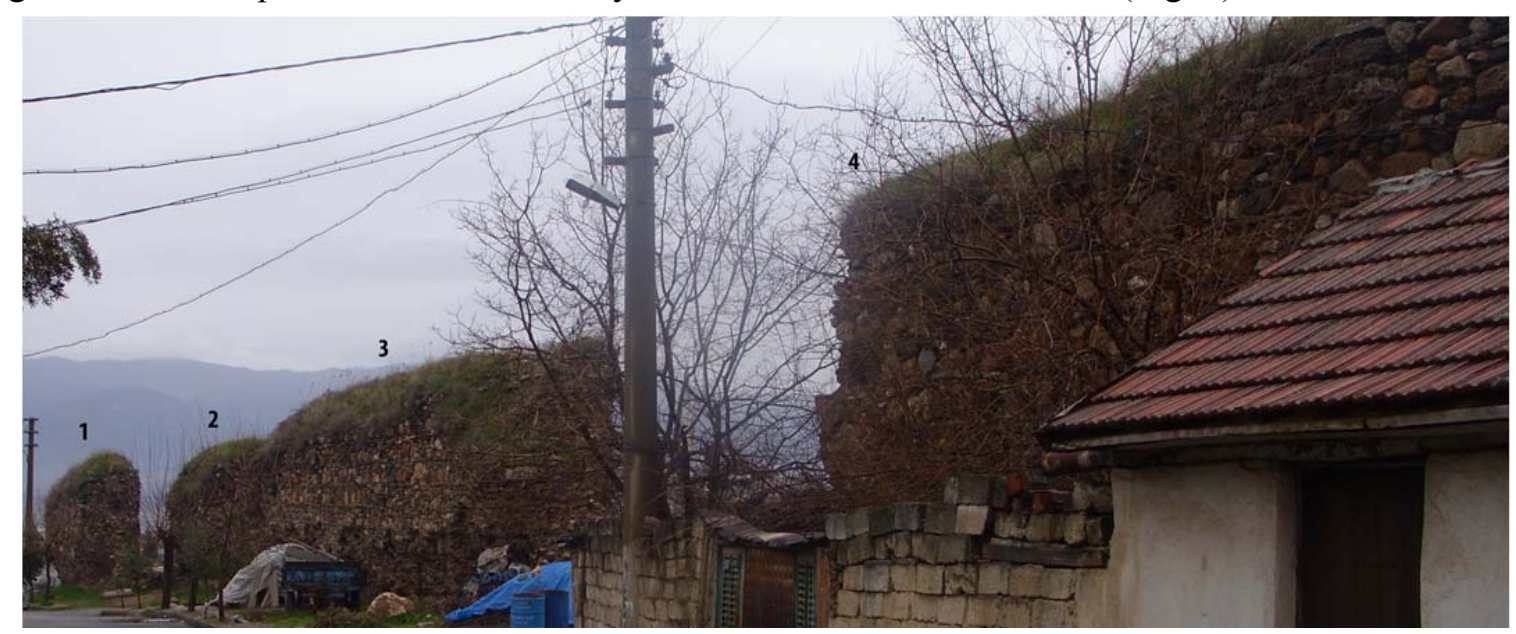

Fig. 2. The City Walls, east section

Wall numbers 22 and 23 differ from the other parts with their well preserved height, width and facing. There is also some evidence of several gates along the west section. One of them is said to have been located between wall numbers 22 and 23 (Zanten 1975, 41-42; Pralong 1984, 110112). What survives today is a semicircular re-entrant at the edge of number 22 . One of the two gates noted by E. Curtius was probably located somewhere in this part. He describes these two gates "as having two monolithic jambs supporting lintels $2.50 \mathrm{~m}$ to $3.00 \mathrm{~m}$ in span, below stone relieving arches of three voussoirs" (Zanten 1975, 41; Curtius 1872, 94. The dimensions of Kiremiçli Kap1, or the gates recorded by Curtius, resemble the two postern gates in the northern section). R. Akınc1, writing in 1949 gives the location of the Kiremiçli Kap1 (Kirmastı Kapıs1) with a photograph of the gate (For the address and the photograph see Akinc1 1949, 10) (Fig 5). Surprisingly, the description given by Curtius matches the photograph. Thus the Kiremiçli Kap1 should be one of the two gates of Curtius, the position of which is either between number 22 and 23 or between number 21 and 22 .

Another gate is located between number 23 and 24 where the city wall turns slightly towards the southeast. Today a part of the gate forms the courtyard of a house, consisting of a barrel vaulted passage about $4 \mathrm{~m}$ wide. In fact the East Gate and the gate in question share some similar features in terms of their form, dimension and relatively defensive position close to the re-entrant angles. In this respect, both of these gates must have been among the main gates of the fortification.

R. Akıncı mentions another gate called the Tabakhane/Tabahane Kapısı. This gate is likely to have been in the west section of the city wall, however a more precise location cannot be provided from the address given by Akınc1 $(1949,10)$.

\section{South Section}

As early as 1871 , Curtius speaks of the south section of the walls as the least well preserved of the sections (Curtius 1872, 94). Pralong associates its lack of its preservation to the topographic features, the akropolis being a source of frequent landslides. According to Curtius's plan, the city wall turns from the east section to the east foot of Toptepe. At Toptepe Hill, it probably ran 
adjacent to the ancient theatre and then joined the west section through some reentrant angles.

Today only two wall traces at the east foot of the hill can be identified with certainty as forming part of the city wall (One of the traces is in Hastane Arkası Sokak (27) and the other (28) at the eastern foot of Toptepe). Whether the small number of traces at the west foot, that form the courtyards or the main walls of the houses are in-situ or have been reused as spolia is unclear. One finds the same at Toptepe. There are no substantial remains that can be ascribed to the city wall here. Curtius mentions some irregular wall remains at the theatre (Curtius 1872, 94). Pralong identifies some traces of a tower in the east foot, as well as drawing attention to the distinct remains of a wall close to the theatre that was faced with cut stones reminiscent of emplekton masonry (Pralong 1984, 112-114).

The only extant gate, called the Elhizar Kapis1 -a pointed brick arch- is situated in the western part of the section, in Uzunoluk or Elhizar Sokak. Today it consists of only a narrow opening rather than being a passage like those of the other gates, probably due to a Turkish restoration. There are two more gates, called the Şehsinan Kapısı and the Hergele Kapıs1, and both of these gates were once in the southernmost part of the section according to R. Akinc1 (Evliya Çelebi also speaks of these two gates, the locations of which contradict those given by Akınc1. See Evliya Çelebi IX. 31, see also Koz 2013).

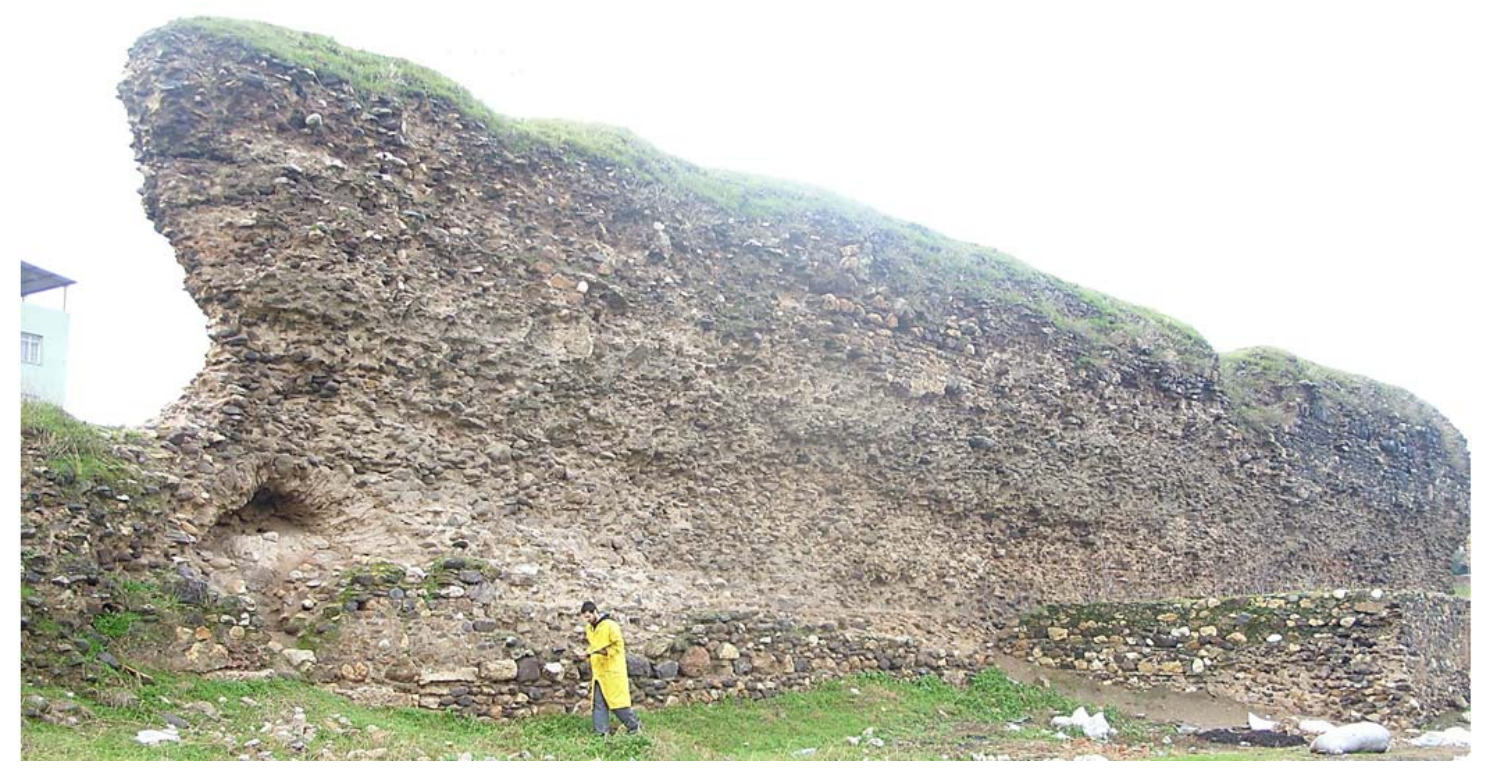

Fig. 3. The City Walls, north section

\section{Dating}

Neither archaeological nor literary evidence helps us in determining a date for the city wall. Nevertheless these remains can be associated with the historical background of Philadelphia through employing a chronological approach.

Strabon's account of the walls of the city may not attest to the earliest period of construction (XII. 8. 18). Nor would the emplekton masonry described by Pralong enables us to date the first phase of the city wall as early as the Hellenistic or from Early Roman rule in Philadelphia due to the lack of evidence (Pralong 1984, 114). In addition, at least the remains that are visible today display integrity as though they were constructed throughout at a particular period of time. Such constructional integrity leads us to the suggestions and comments made by Foss and van Zanten et al. who underscore the great number of common characteristics between the city walls of Sardis and those of Philadelphia. From this point of view, Foss dated both city walls to the same 
period, with those of Sardis carrying finds datable to the late third century and he reasoned both were constructed during the period of the Goth raids in Anatolia (Foss \& Winfield 1986, 128, 162; Zanten 1975, 41- 42).

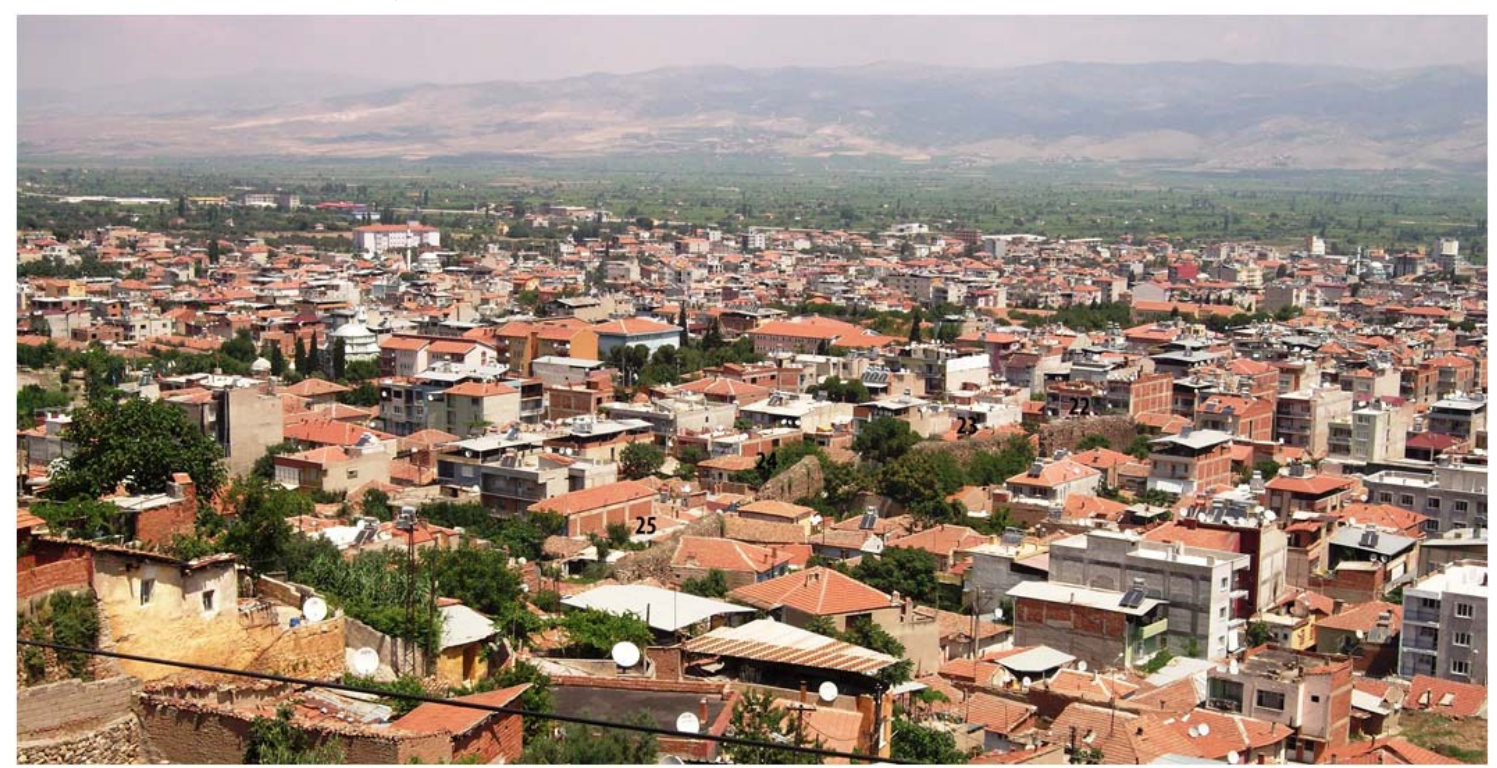

Fig. 4. The City Walls, west section

Despite the fact that the earliest period of construction of the city wall is undetermined, there is some evidence unsurprisingly suggesting that it has been restored and modified over the course of the centuries. Such evidence can be obtained through observation and from some written sources.

The blockage of gates, the distinctive facing features of the towers in the east and south section, perhaps, also some other traces noted by Pralong, indicate the long term exploitation of the city wall, while the time-frame of these alterations cannot be precisely ascertained. Further, both the chronicles and the ecclesiastical references, most of which date from the $\mathrm{XI}^{\text {th }}$ to $\mathrm{XIV}^{\text {th }}$ centuries show the city wall continued to be used, with probable restorations or reinforcement (The towers to the south of the East Gate and to the southeast corner of the wall number 3, as well as that at the north-eastern corner of the city wall would have been renovations dating from the period of Komnenos or Laskaris, as Pralong also cited in 1984, 124. For similar examples to the facing of these towers, see in general: Foss 1979, 297-320 and 1982, 145-205. For the historical events and literary evidence associated with probable restoration and the long term survival of the city in the period mentioned above, see Foss 1991, 1648-1649; Laiou 2002, 479; Tok 2010, 303-311; Foss 2011, 99 fn. 177, 114). During this period of Turkish expansion, Philadelphia bore witness to many battles against the Seljuks and also undertook many important functions.

\section{A Fortress at Toptepe?}

The Akropolis/Toptepe that is to the south of the city carries few traces of its past. The theatre and the so-called tower of a fortress are the only remains that can be certainly identified today. Even though past studies and excavations inform us of some remains, most of these are not visible today (Among these are the theatre, the temple of the theatre, two towers, the remains of the city wall (?) and various remains of structures from the East Roman period), do not provide enough information to determine the plan of the akropolis. Also the lack of information in publications dating from more than a century ago may attest to the scantness of remains at 
Toptepe at that time (Curtius mentions the lack of remains while travellers report no remains on the akropolis in the $19^{\text {th }}$ century. See Curtius 1872, 94).

Neither of these remains show the historical transformation of the akropolis at present, but may provide some indications. R. Meriç, writing in 1987 and 1990, speaks of the few remains of an East Roman fortification encircling Toptepe. He also reported that the fortification has rectangle towers at regular intervals and the beveled curtain walls are faced with cut-stone. A number of cleaning and arrangement works are said to have been conducted at the east and west towers of the fortification as part of season's excavations (Meriç 1987a, 244; 1990, 181).

Apart from Meriç's reports, there remain today no substantial traces of a fortification. Neither travellers, nor researchers draw attention to any such a structure. Today only the so-called West Tower which can be ascribed to one of these towers remains visible. It is located at the western foot of Toptepe and is about $70 \mathrm{~m}$ east of the theatre (Fig. 6). It is rectangle in plan and its dimension are c. 3.

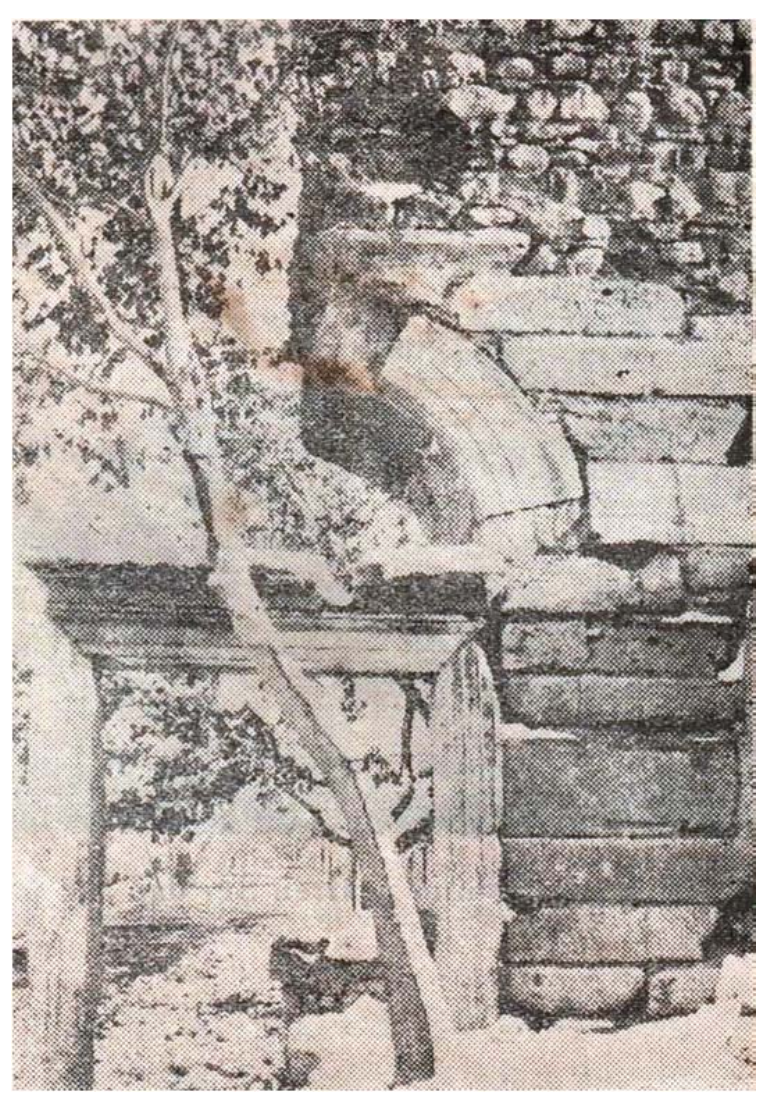

Fig. 5. The City Walls, west section, Kiremiçli Kapl. Akınc1 1949, 10

$0 \times 6.0 \mathrm{~m}$ at ground level. The facing of the northwest wall is partly preserved, faced with rough cut and rubble stone and there are also four courses of brick in the upper part of the wall and tile fragments filling the gaps between the stones (Such a facing, the alternation of brick and stone courses and filling the gaps with fragments of tiles which has a rough cloisonné-like arrangement, resemble in particular the fortifications constructed under Komnenos and Laskaris. See in general Foss 1982, 145-205 and 1979, 297-320). In the southwest side there is a stairway leading to the ground or upper floor. The Eastern Tower, the location of which we could not find today, is about $70 \mathrm{~m}$ to the east of the West Tower according to the preservation site plan of the city (The only remains in the map are the temple between two towers, the theatre and a part of the city wall (?) in the southernmost part of Toptepe).

It is hard to establish from these remains, what was the former appearance of this fortification. Therefore, not to go beyond the supportable indications: The facing character of the so-called West Tower is irrevelant to any curtain wall of the city wall and likely indicates a later period. Further, a considerable number of pottery fragments, coins, tombs, as well as some wall remains from houses uncovered during the excavations at the Theatre and the Theatre Temple are reported, that can mostly be dated to the Late East Roman period (Meriç 1986, 259260; 1987a, 244; 1988, 159; I suppose the expression employed, "Late Byzantine" suggests the period of Komnenos or Laskaris and thereafter). All of which may lead us to the question: would there have been a Kastron located on the hilltop of Toptepe? It is easier to ask than to answer this question, but all the remains and finds show that there was once most probably a settlement inhabited at least until the last centuries of East Roman rule in Philadelphia. 


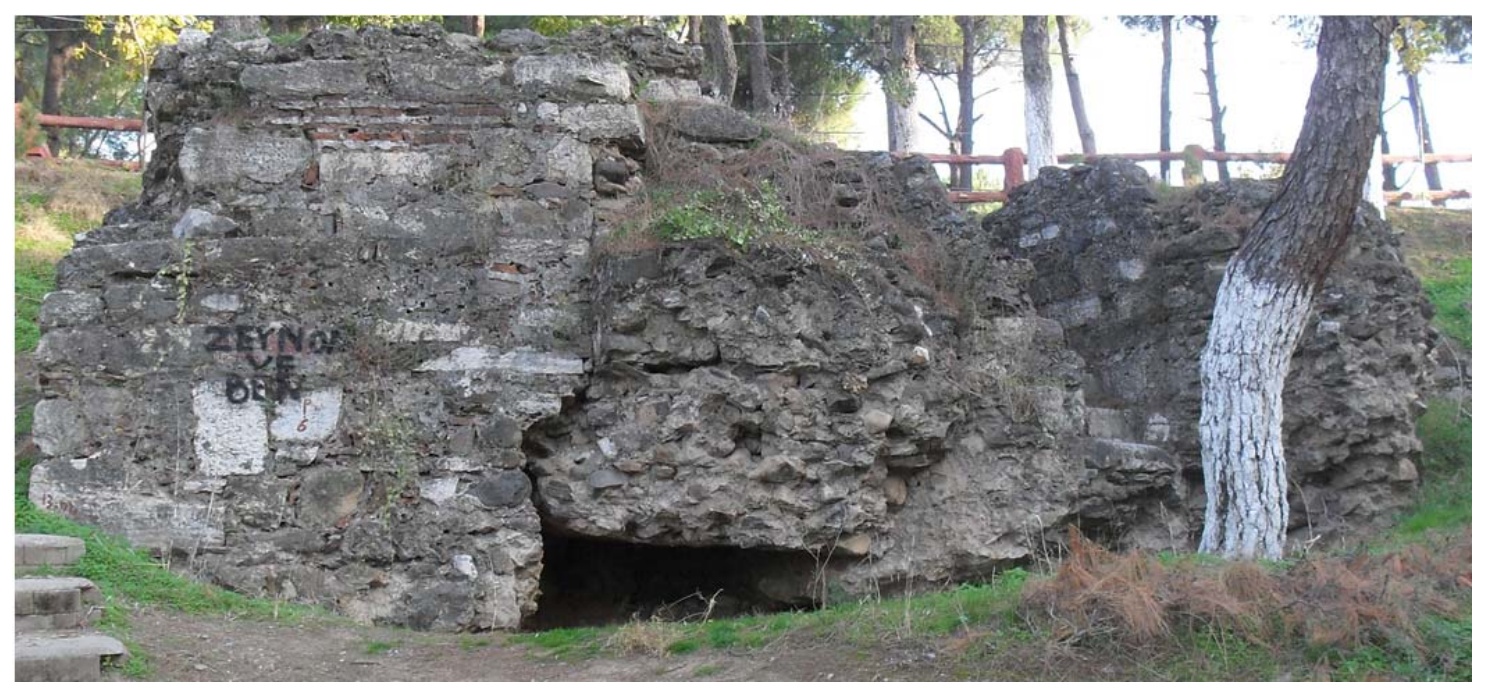

Fig. 6. Toptepe, west tower (?)

\section{Galleries/ Sewers}

The galleries that lay beneath Alaşehir and within the walled precinct are one of the lesserknown remains of Philadelphia. There are no detailed descriptions of their layout, the construction techniques employed, materials, dimensions etc. Nevertheless, some local researchers provide a certain amount of information concerning these galleries. Having witnessed cleaning work in one of the galleries in İstasyon Caddesi in 1946, Akıncı describes them as being 4 to 5 meters underground, 1 meter wide and 2 meters high and paved with stones (Akinc1 1949, 98). There are also a number of suggestions that have been made regarding the locations of these structures. Akınc1 reports that some of the galleries were identified in İstasyon Caddesi, Beş Eylül Mahallesi and Sarısu Mahallesi. Another researcher stated there are two galleries about 350 to 400 metres long, extending from the Güdük Minare Camii to the railway and from the vicinity of Yıldırım Bayezid Camii to Dombay Kapı (Akınc1 1949, 98; Ceylan 2004, 136-137).

One of these galleries was recently discovered during infrastructure work in Sevgi Yolu, Sekine Evren Caddesi in 2013, and was then infilled, unfortunately without providing any detailed report. M. İbişoğlu, the deputy mayor of the city, provides information from his observations that the gallery was about $1.70 \mathrm{~m}-1.80 \mathrm{~m}$ wide and $1.20-1.30 \mathrm{~m}$ high and was covered by a vault. It was constructed of stones and bricks. He also reported that a number of clay pipes were identified along the gallery (interview with Muammer İbişoğlu (01.06.2015)).

While these structures are in general termed galleries, the general view is that these structures belonged to an ancient sewerage system (Some suggested that these galleries served as escape routes). At this juncture, a written source surprisingly presents supporting evidence for a sewerege system in Philadelphia and provides a terminus ante quem: According to Zosimos, a conflict occurred between the Egyptian and barbarian soldiers in Philadelphia in Lydia in the reign of Theodosios and "...more than two hundred were killed, others wounded and the rest forced to flee to the sewers, where they died (Zosimos IV. 30; see Ridley 1990)." 


\section{The House with Mosaics}

The remains of a part of a building with a mosaic pavement, which probably formed part of a house was uncovered during an illegal excavation in Sarısu Mahallesi, Sümer Oral Caddesi, no. 262, within the walled precinct. The building was investigated, especially the mosaics, and subsequently published by E. Tok in 2011 (Tok 2011, 51-66), we did not however have the chance to see these remains as any entry into the plot remains prohibited.

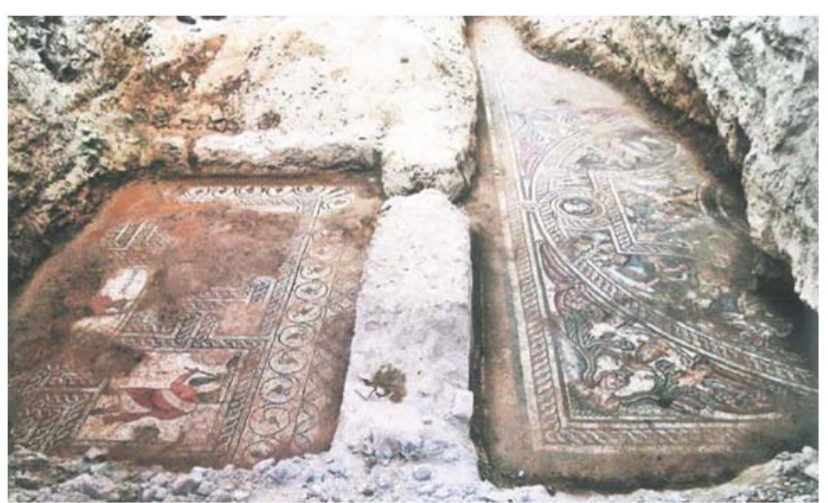

Fig. 7. The House with Mosaic. Tok 2010 (Fig. 1).

Amongst these remains, most of which continue beneath the residential housing, two rooms (number 1 and 2) with mosaic floors and a cellar were identified (Fig. 7). All of the walls are built from stone and brick joined with by Khorasan mortar (Tok 2011, 52-53).

The cellar is located beneath room number 1 and is covered by a barrel vault of tiles. It is suggested that other vaulted cellars are beneath the room (Tok 2011, 51).

The large part of the larger room (room number 1) is covered in earth and therefore its overall dimensions cannot be determined. The visible longer edge measures $9.90 \mathrm{~m}$. The inner face of the walls of the room were once revetted with marble plaques, however today only some fragments can be seen. There are also the remains of heating pipes between the wall and marble plaques providing evidence of the house's heating system. The visible dimensions of the smaller room are $2.75 \times 3.55 \mathrm{~m}$. Like the larger room, the inner face of its inner walls was revetted with marble plaques (Tok 2011, 52- 53).

Both of these rooms have mosaic pavement consisting of geometric, floral and figurative designs. The mosaic floor of the larger room carries depictions of the Seasons and of Okeanos and Tethys, while the smaller depicts Dionysos and Silenos, in addition to the geometric and floral ornamentation. E. Tok suggested two periods for the mosaics on the basis of the repairs, color, design and style and dated the mosaics of Room number 1 to the third century, the other to the fourth century (Tok 2011, 51, 65).

Because most of the remains have not to date been excavated, it is difficult to determine the exact layout or plan of the house. Nor is it possible to tell if these remains belong to a characteristic Mediterranean peristyle house or to some other house type/variant, such as with apsidal chambers or belonging to the subdivided houses of Late Antiquity. Nevertheless some basic suggestions can be made: the traces of the wall revetment and the heating pipes, as well as the mosaic pavement of good quality, most probably indicate a luxuriously decorated wealthy house, the layout of which may belong to one of the types mentioned above. Some predictions can be also made based upon the dimension and the design of these rooms. With its rich mosaic decoration and marble revetment, the larger room might have been used as the main reception area of the house, maybe a triclinium. In addition, the two mosaic panels of the room in front of the cellar carrying geometric and floral designs differ from the bulk of the mosaic pavement with figurative scenes. Such a different layout of the pavement may be indicative of the location of furniture, the division into parts serving different purposes or the desired flow of movement as Dunbabin has pointed out (Dunbabin 1999, 304). The other room is relatively smaller and could be a part of one of the subsidiary rooms or a wing of courtyard, if there was one. 


\section{Burial Sites}

While the discoveries of the $20^{\text {th }}$ century have cast some light on our knowledge of cemeteries, little is known of the ancient nekropolis of Philadelphia. Even worse, is that rather than archaeological excavation, the information concerning such remains has for the most part been obtained from infrastructure works in the city, which have largely caused the partial or the total destruction of these remains.

The few remains which are somehow ascribed to an akropolis or a cemetary have been uncovered during recent research and excavation during the last decades. Karakaya alleges that there were akropolises both in the east and west parts of the city, immediately outside the city wall. However, almost all of the remains have been discovered in the west part (Karakaya 1995/ 1996, 54). In addition, the Gavurtepe Mound, the earliest settlement of the city, has also been suggested as being in part used from the Late Hellenistic Period onwards as a cemetary (Meriç 1989, 180). Since the archaeological remains are both scanty and scattered around the city as a result of spoilation, it is difficult to determine the exact period of use of these cemetery sites. Nevertheless, at least, in a general manner, the West Akropolis can be assumed to have been used as early as the Roman period and subsequently to some degree in Late Antiquity (See in general: Karakaya 1995/ 1996, 54-60).

Concidering the Late Antique and East Roman periods, more is known concerning the layout of the burial sites in comparision with earlier periods, due to archaeological excavations and infrastructure works. Uncovered in Gavurtepe Mound and Toptepe, these burials are generally of ordinary people, built of spolia or bricks and mostly lay over earlier settlement and sometimes within another earlier cemetery (For burials unearthed in excavations see: Meriç 1986, $260,262 ; 1988,158 ; 1989,180-181 ; 1992,228-229 ; 1993,356)$. However, apart from these sites, there must also have been intramural burials in buildings, such as those within the Church of Saint John the Theologian, and in different parts of the city.

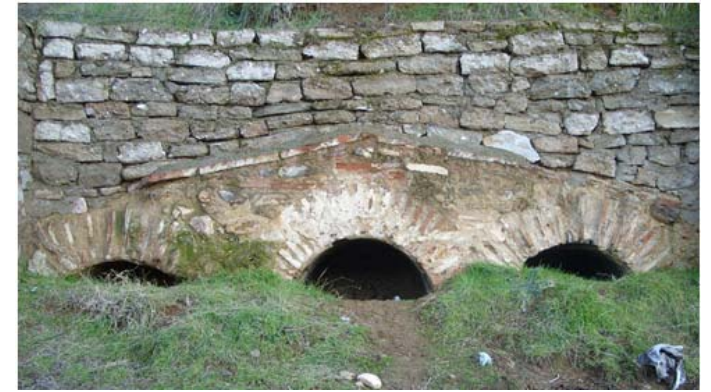

Fig. 8. Hypogaea

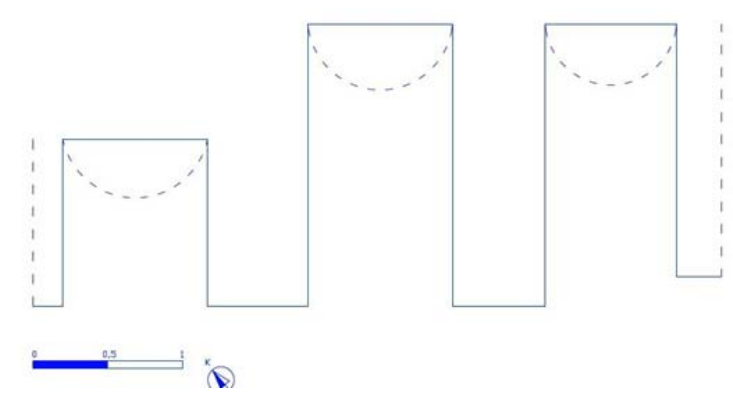

Fig. 9. Hypogaea, plan

Today, among noteworthy remains are a group of chamber tombs located at the west foot of Esentepe, which is also said to form a part of the west nekropolis. In 1976, twelve hypogaea were discovered and were partly damaged during the course of road construction (Mellink 1977, 319). About a decade later, unfortunately only half of them remained, today only three hypogaea are visible (Fig. 8) (For a more detailed description see Karakaya 1995/ 1996, 54). I would briefly like to introduce these tombs respectively numbered 1, 2 and 3 from east to west (Fig. 9).

All of these tombs are oriented on an east-west axis (At least one of the hypogaea is reported to be orientated on a north-south axis), rectangular in plan, covered by a barrel vault of tiles and faced with a brick arch to the west. The entrance to the hypogaea was once provided by a trap door from the western face, these are destroyed today (Mellink 1977, 319. For a similar entrance system in Sardis see Mellink 1977, 309; Karakaya 1987, 21). The surfaces of the 
interior walls and the vaulted ceiling of two chambers are plastered $(1,3)$ (The other three unpreserved hypogaea are reported to have been only plastered. See Karakaya 1995/ 1996, 57), while the other (2) is also painted with frescoes including the colors: red, black, blue, green and yellow. Since today the interior of the chamber is partly covered in earth and debris, the frescoes are not in a well preserved condition and the wall paintings can barely be identified (only the traces of garlands, flowers and one basket with fruit on the eastern lunette). According to earlier accounts, the inner surfaces of all the hypogeum were decorated with frescoes carrying design of flowers, baskets with fruit, worm-like garlands and partridges (For a more detailed description concerning these fresco depictions see Karakaya 1995/1996, 56- 57), all these depictions being reminders of the ethereal life.

Because these three hypogaea were built parallel and adjacent to each other, as well as there being a pediment of tiles placed above these three hypogaea (The pediment is reported to have covered another hypogeum. See Karakaya 1995/ 1996, 57), it is plausible to suggest that this group of tombs was designed for a single family (See also Karakaya 1995/ 1996, 57). Morever, hypogeum 1 is much smaller $(1.12 \times 0.97 \mathrm{~m})$ than the others $(1.89 \times 0.88 / 97 \mathrm{~m})$ and could have been designed for a baby or a child, while the painted tomb should belong to a dignitary (of high rank).

The date of the hypogaea is unknown, due to the lack of evidence. There are some similar examples in terms of plan and fresco adornment in many part of Anatolia, especially in neighboring Sardis, and Constantinople most of which date from Late Antiquity (For comparable contemporary examples, see Mellink et al. 1968, 41; Karakaya 1987, 18-27; Kongaz 1988, 117-129; Gates 1995, 249-250; Ermiş 2011, 121-139)

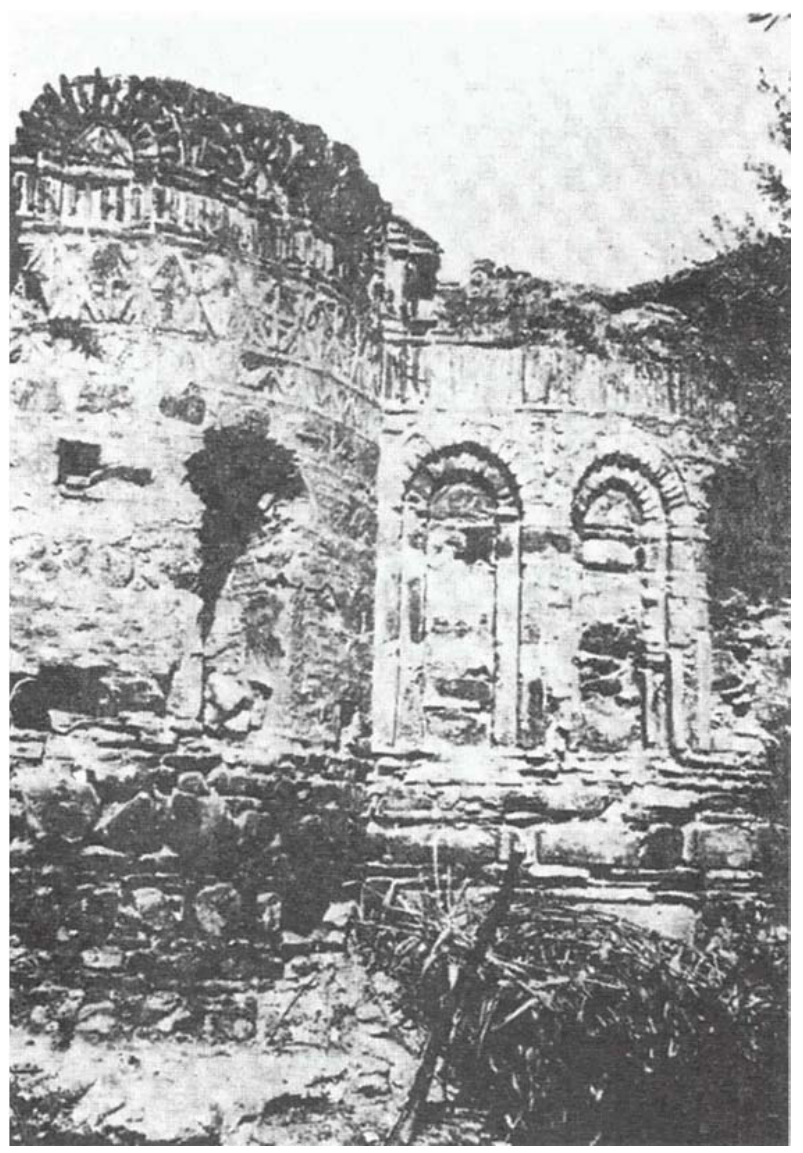

Fig. 10. The Church of the Prophet Naum. Lampakis 1906, 378

\section{Churches and Monasteries}

There are only two churches dating from Late Antiquity and the East Roman period known for certain to have been located in the city centre, the Church of St. Ioannes and the Church of the Prophet Naum. While the ruins of the former are extant, the latter has not survived to the present day (Since both buildings have already been studied, I will briefly mention them below providing some additional current information). Apart from these two buildings, contemporary sources provide no detailed information concerning the fate of the other churches of the period in the city.

Nonetheless, the accounts of the travellers provide some useful references to Christian churches, albeit in a sketchy form. Visiting Philadelphia between 1764 and 1765 and the second 
half of the $19^{\text {th }}$ century, almost all the travellers to the city reported that it had 25 churches, 20 of which were disused as they were either too old or too small. Christian divine service was performed weekly in five of these churches, but in the other twenty, only once a year (See Arundell 1828, 170; Hartley 1831, 305; Milner 1832, 318-319; Allom 1838, 72; Newbold 1852, 88; Chandler 1971, 198; Texier 2002, 84). Some travellers also recorded the names and features of several of these churches. Among them, the Episcopal church, "large, and ornamented with gilding, carving and holy portraits" (The Church of St. Ioannes? Chandler 1971, 198), the Panagia, St. Dimitri, St. Theodore and St. Michael (Texier 2002, 84). Newbold also spoke of the churches as "small and mean, and contained many fragments of columns and ancient sculpture" (Newbold 1852, 88).

To be sure, it is difficult to claim with certainty that all of the churches recorded by the travellers date from the period in question. However, some, even a large number of them, it can be suggested were constructed prior to the establishment of Ottoman rule in Philadelphia, considering the firmans which, to a great extent forbade the construction of churches until as late as the last quarter of the $18^{\text {th }}$ century, as well as Chandler's account of 1764-65 which records most of the churches were already in ruins (For general comments on the firmans and observations see Karaca 2008, 27-54; Pekak 2009, 171-204).

Two monastic foundation documents dating from the Middle East Roman period, record the presence of extramural monasteries and related buildings in the vicinity of Philadelphia. One of these is the "Testament of Maksimos" (A later copy of the testament with an updated register from a little after 1258 is extant in the archive of the Vatopedi Monastery on Mount Athos. See Thonemann 2011, 179) dated 1247, which provides information about the process of establishing, annex buildings and provides a detailed inventory of the possessions of the monastery. It also contains valuable clues concerning the lives of the monks at that time (Thomas \& Hero (Eds.) 2000, 1176-1195). The monastery was within the diocese of Philadelphia (Nasturel 1984, 82; Thomas \& Hero (Eds.) 2000, 1191), however, its exact location is uncertain (For comments concerning its location see Nasturel 1984, 82-85; Thonemann 2011, $178 \mathrm{fn} .2$ ). Another document, probably dating from the last quarter of the $\mathrm{X}^{\text {th }}$ century, consists of two inscription found in-situ to the west of Alaşehir, on Mount Tmolos, Soğukyurt Village (Azıtepe Village), where there are also the ruins of the building complex. Today the site is covered by debris, with little remains of architectural plastic elements lying partly on the surface, dating from the Late Roman to the $\mathrm{XI}^{\text {th }}$ century. The inhabitants also state that a number of chambers adorned with frescoes lie beneath debris. The small number of remains do not enable us draw even a sketch of the layout of the monastery. But the inscriptions and some of the fragments of architectural plastic witness to at least an "Old Age Home" and perhaps a "Katholikon" located within this monastery (For commments on the inscriptions and the remains of the monastery in the Village of Soğukyurt (Azıtepe) see Meriç 1987b, 247-248; Drew-Bear \& Koder 1988, 197-215; Thomas \& Hero (Eds.) 2000, 310-312).

\section{The Church of the Prophet Naum}

The earliest report concerning this church was the publication of G. Lampakis in the early $20^{\text {th }}$ century, including a short description with a photograph of a part of the east façade (Fig. 10) (Lampakis 1906, 377-378). Apart from the photograph, we lacked any tangible evidence until recently. Visiting Alaşehir in 1975, Buchwald found no remains of the church (Buchwald 1979, 279 fn. 70), whilst Mercangöz, having completed her PhD in 1985, asserted that “...the building was destroyed recently and a water reservoir built on its site" (Mercangöz 1985, 152).

Because the church has already been examined (Buchwald 1979, 279-280; Mercangöz 1985, 
152-153), I will briefly introduce it, based upon the photograph of Lampakis. Only the main apse, presumably with five sides and one of the minor apses semicircular in plan are visible. The uppermost part of both of apses, in particular of the main apse, and the roofs had collapsed.

Both apse are divided into three sections, carrying stone and brick facing in the lower section, blind arcades and windows in the middle section, and brick ornamentation of various patterns in the upper section.

The lower section of the facing of the main apse appears to be constructed of courses of ashlar and bricks. The ashlars in the main apse also seem to be framed by vertically placed bricks, reminiscent of cloisonné. The lower facing of the minor apse is similar to that of the main apse, however, here rubble like stones were applied and vertical bricks are not visible.

In the middle section of the main apse there is a window and two blind brick arcades recessed twice. There is also a window in the middle section of the minor apse.

The most articulated section of the facade is the upper section, consisting of horizontal friezes of bricks and forming designs such as zigzags, crosses inscribed in lozenges, meanders and the like. In the uppermost part of the friezes of bricks in the minor apse there is another blind arch recessed twice (Buchwald asserted that the lunettes seen in the photograph are also decorated with brick patterns, including inverted " $V$ "s. See Buchwald 1979, 279) and seemingly, a sort of Khristogram immediately to the right of the blind arch. At the same level of the main apse there seems to be the springing of a brick arch recessed twice, perhaps of a small window, as Buchwald has suggested (Buchwald 1979, 279).

Since we have neither a plan nor a complete photo of the church, our comments are limited to the evidence recorded in the photograph of Lampakis. The first remarkable point is the facade articulation composed of bricks arranged in diverse patterns. In brief, such brick ornamentation can be traced in the facades of East Roman churches especially those dating from the Middle East Roman period onwards in many part of the empire. However, when considered locally, it is clear that the most similar examples to that of the facade of the Church of Prophet Naum are the churches dating from Laskaris, particularly those in Western Anatolia (Buchwald dated the building to the period from about 1250 to about 1265. See Buchwald 1979, 293. For comparable church facades from the Laskaris period, especially in Lydia, see Buchwald 1979, 261-296; Mercangöz 1985, 118-152; Mercangöz 1990, 117-138).

The second suggestion is rather hypothetical. As far as we can see in the photograph, the church must have had three apses, rather than five. Even though such a feature does not exactly attest to a specific plan type of the period, when one associates the photograph with the characteristics of the architecture and the decoration of the time, it seems reasonable to say this church most probably had one of the plan variations of the centrally planned churches of the Middle and Late East Roman periods (Perhaps a cross-in-square church or, less probably, the other domed variations).

\section{The Church of St. Ioannes}

Located almost in the center of the city walls, the Church of St. Ioannes is the only surviving church within the ancient city. Today it is called "Üçayak" or "the Church of St. John", its original name is uncertain (The earliest reference to its name or title (episcopal) may have been the account of R. Chandler who speaks of one of the churches in Philadelphia in the second half of the $18^{\text {th }}$ century as "...The episcopal Church is large, and ornamented with gilding, carving and holy portraits..." (See Chandler 1971, 198). By the early $19^{\text {th }}$ century the church has already come to be known as having been dedicated to St. John. (See Arundell 1828, 170. See also Elliott, 1838, 89). After some brief account made by travellers and researchers beginning in the 
second half of the $18^{\text {th }}$ century (Arundell 1828, 170; Elliott 1838, 89-90; Hamilton 1842, 375; Kitto 1856, 518; Choisy 1883, 160 and plate XVI/I; Strzygowski 1903, 36; Lampakis 1906, 375-377), an exhaustive study concerning the church was only published by Buchwald in 1981 (Buchwald 1981, 301-318). Subsequently, a number of archaeological works were carried out by R. Meriç and the church was investigated as part of the studies concerning the early churches of West Asia Minor (Meriç 1986, 261; 1992, 229, 233-235; 1993, 356-357, 362-363; Karydis 2011, 16-18/117-133/176-177).

Travellers accounts show almost all the church was already ruined by the early $19^{\text {th }}$ century, with only its four partly standing piers from which the remains of brick arches rise, part of a wall of the choir and some damaged frescoes surviving and, today the site of the church functions as an open air museum with the four piers, one of which is preserved only to ground level, and a number of artifacts brought from neighbouring Alaşehir.

As only the four piers of the building are extant, most suggestions can not go beyond speculation until a thorough excavation has been conducted. Nonetheless, one may investigate the basic characteristics of the church in the light of recent research.

The best preserved pier is located in the northeast (Fig. 11). It is about $14.50 \mathrm{~m}$ high with the brick vault fragments surmounting it (For the alleged floor level see Meriç 1993, 356). All its faces are made of ashlar masonry, while the north and especially the east faces are damaged, and subsequently partly restored. At the top of the pier is the stone string course which is extant only on the south and west sides. In plan, the pier has straight edges on the north and east, while on the south and west it has profiles with re-entrant angles indicative of the

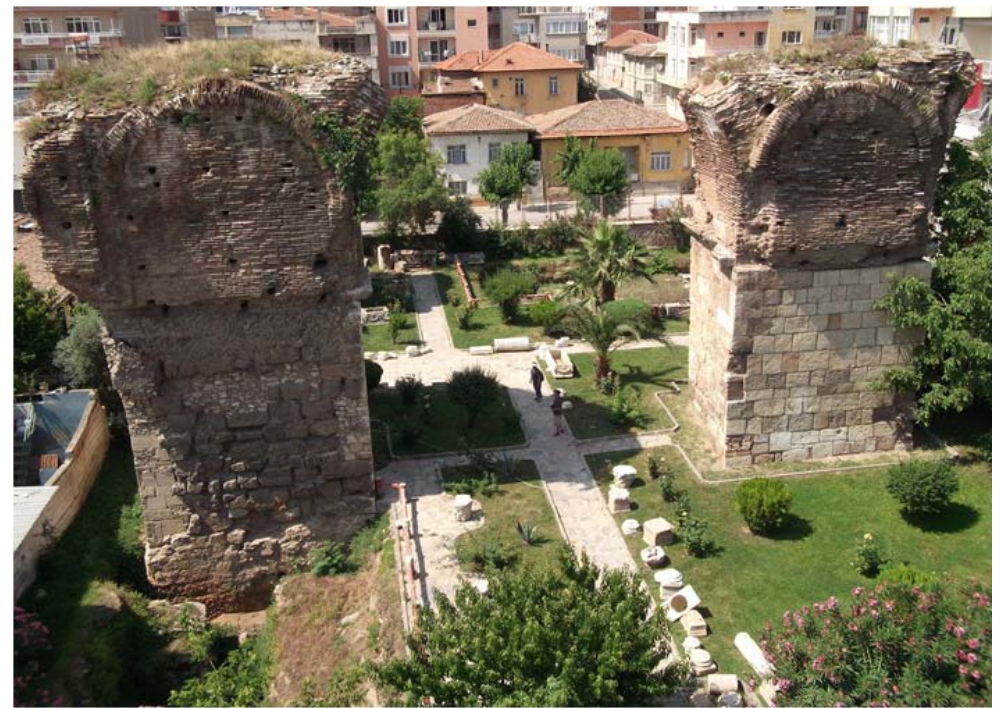

Fig. 11. The Church of St. Ioannes, $N E$ and NW piers from North surmounting arches. Today among the vault fragments one can trace the springing of the arches on the west and south, a pendentive fragment at the southwest corner, as well as the facades articulated by blind arches recessed twice on the north and on the east with saw-tooth brick ornament.

Similar characteristics to the northeast pier can be traced on the northwest pier. It is faced with ashlar blocks which are well preserved, and with few bricks placed into the joints, except for the restored north face. Another string course was placed on the east, west and south sides of the pier at the same level as that of the northeast pier. One can distinguish the similar profiles with re-entrant angles in plan on each side, with the exception of the north, which is straight, as well as the remains of the bricks arches on the east, west and south; two pendentive fragments, although difficult to trace, at the southeast and southwest corners; and the blind arches on the north which are recessed twice, as in the north and east facade of the northeast pier (Only one brick fragment, which may be associated with saw-tooth ornament, is extant on the east extrados of the north blind arches of the northwest pier). 
The southeast pier is not as well preserved as the other standing piers. It is faced by ashlar blocks, some joints of which are filled with brick and brick fragments, as in the northwest pier. However, the east and south facings have to a large extent been damaged. There also seems to be another string course that articulates the north and west sides of the pier. The pier in plan also has profiles with re-entrant angles on the west and north. The vaulting remains of the pier consist only of brick courses of the lowest part of the vault, rubble core and the ashlar blocks in the lowest course, like the other piers. Neither the springing of the arches nor any remains of the pendentives have been identified.

Today the southwest pier is only preserved to a height of about $1 \mathrm{~m}$. Nonetheless, this lowest part of the pier also appears to carry the characteristics of the other piers. Its faces are of ashlar masonry and brick occasionally placed into the joints.

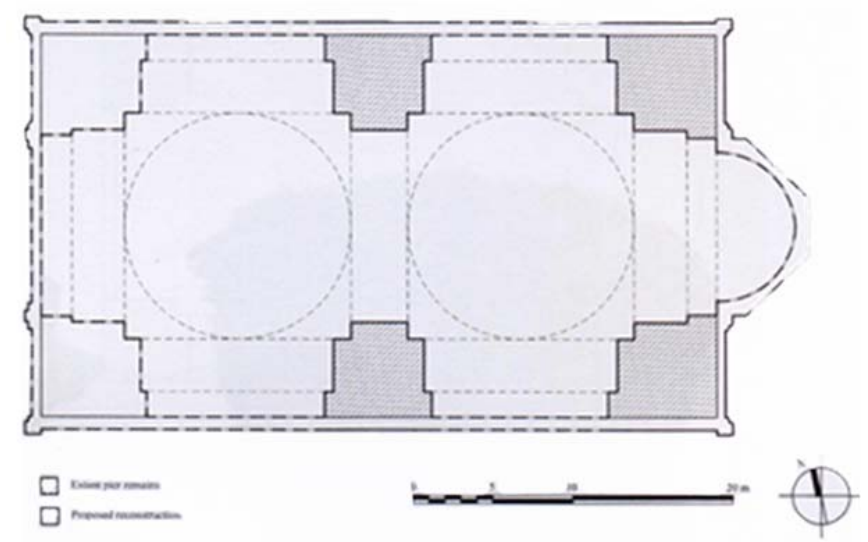

Fig. 12. The Church of St. Ioannes, reconstructed plan (drawing by Karolina Vasilikou). Karydis 2011 (Fig. 16) The profiles with re-entrant angles are extant on the east, west and north.

At least the piers, and presumably the arches, were once covered in frescoes, most of which, apparently already in the early $19^{\text {th }}$ century, were damaged (For the earliest references to the frescoes, see Elliott \& F.R.S. 1838, 90; Lampakis 1906, 375-377). One can infer from the accounts of Lampakis that over the past hundred years, the remains of these frescoes have continued to erode away (Buchwald noted that the numerous fresco scenes described by Lampakis were no longer recognizable in the 1970's). Today only a few of these may partly be discerned on the surfaces of the south and the west faces of the northeast pier, the north face of the southeast pier, and on the uppermost part of the intrados of the narrower arch on the east side of the northwest pier. The very poorly preserved remains on the surfaces of the east, west and south faces of the northwest pier must also have been of frescoes, rather than plaster.

Unfortunately the fresco remains retain today, neither any complete stylistic feature nor any identifiable narrative scenes. Only a few of those which once adorned the surfaces of the south and west sides of the northeast pier are partly recognizable today. Among them, which Buchwald had the chance of identifying in a relatively better condition (See Buchwald 1981, 309-311), are probable busts of saints with halos, some of whom also appear to have epitrakhelion with crosses and Bible inside a row of roundels immediately below the string course on the south side of the northeast pier. Beneath one of the roundels is an (unreadable) inscription which can barely be discerned. The slightly recognizable red lines must have bordered the depictions or the broader scenes. Among the fresco remains, shades of the colors blue, red and yellow seem to dominate. The figures represented on the west side of the pier are less preserved than those on the south side of the pier. There is a frontal figure probably with a halo below the string course (See also Buchwald 1981, 310) and two figures facing each other, one of which has a halo about a metre below the frontal figure. A row of heads, some of which are covered by pointed hoods, as Buchwald has pointed out, may also be partly distinguished below the two figures facing each other. Similar shades of colors are extant on this west side of the pier, suggesting they are from the same period. 
The vault fragments demonstrate that the Church of St. Ioannes was covered by at least two pendentive domes or domes on pendentives, while its original plan is uncertain (Fig. 12) (See Buchwald 1981, 312, Karydis 2011, 17, 130). Based upon his reconstruction plan, Buchwald compared this church with a number of domed churches and suggested that the church might have been built in the age of Iustinianos (The church without doubt, finds its closest counterpart in terms of its ground plan and the nature of the fragments of the piers and the vaults, in Building D at Sardis, constructed probably before the VII ${ }^{\text {th }}$ century. For a comparision between the two churches see Karydis 2011, 181-182, see also Karydis 2012, 122-138. For the observations on comparable contemporary churches, most of which were built in Western Asia Minor and, in a similar manner to the Church of St. Ioannes, see Buchwald 1981, 317-318; 1984, 209-215; 1986, 6-7; Karydis 2011, 1-182). Since in the absence of evidence of the two piers which originally supported the second dome, and as the extant remains provide no evidence for the west section of the church, there is no point at present in arguing about the possible existence of any third dome, or a narthex/an atrium (See also Buchwald 1981, 312). Nevertheless, on the basis of the remains and the excavation results, we can at least argue whether the church once had aisles and galleries or not, and correspondingly also whether or not the north and east sides of the northeast pier, the north side of the northwest pier and the south

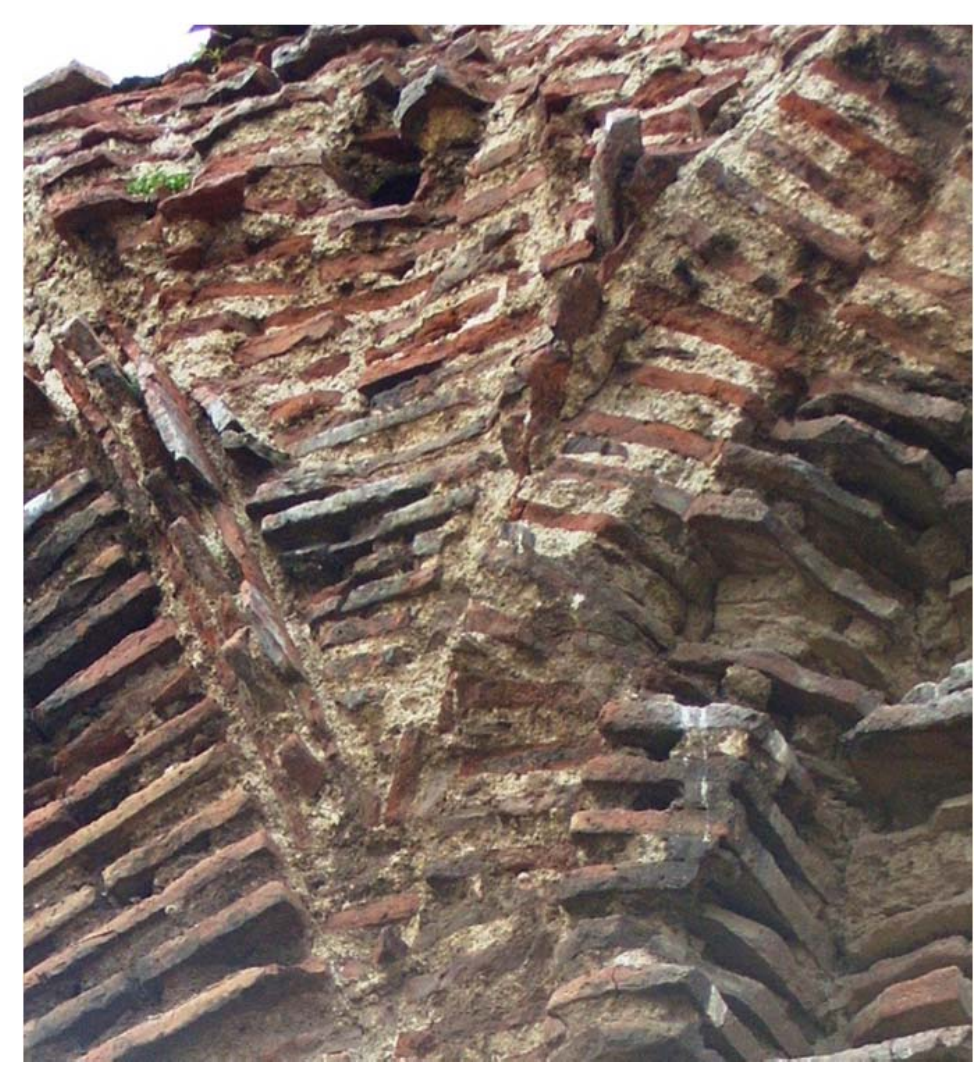

Fig. 13. The Church of St. Ioannes, NE pier from east, saw- tooth band, detail side of the southeast pier were indeed a part of the exterior of the church. At this juncture Buchwald provides two solutions. The first is the inscribed aisles which have side aisles and galleries between the piers beneath the arches and the second is the additive aisles which have aisles added to the exterior of the piers. However, neither of these solutions led him to suggest that the church was originally built with side aisles and galleries (See Buchwald 1981, 314). Actually, the piers and the vault fragments provide many clues for us to agree with him, and to suggest that at least the additive aisles did not occur and also, the aforementioned sides of the piers were a part of the exterior of the church from the start.

The absence of frescoes, of the springings of arch and string courses on the north and east sides of the northeast pier, from the north side of the northwest pier and from the south side of the southeast pier, as well as the presence of facade traces such as the brick blind arches recessed twice on the north side of the northwest pier and on the north and east sides (For the facade traces, see also Buchwald 1981, 312-313; Karydis 2011, 17, 126-127, 176-177) of the northeast pier support the suggestions mentioned above. In addition, as Karydis noted, the idea of the 
absence of aisles can be once again supported if the straight walls adjacent to the north side of the northeast pier and to the south side of the southwest pier on the east-west axis (These walls, about one metre thick were exposed during the excavations. See Meriç 1992, 229; 1993, 357. At least the one at the southwest pier was faced in alternating brick and stone courses) in the very first phase (which were exposed during the excavations) "enveloped the piers enclosing the central, aisless space of the church" (Karydis 2011, 17).

Lastly, I would like to investigate the evidence for the later phases of the church. At first sight, the brick facade articulation mentioned above appears to be of a part of alterations dating from the Middle or Late East Roman period (Karydis noted that Castelfranchi also ascribed these facade articulations to the Middle Period. See Karydis 2011, 129). However, the suggestions of Buchwald and Karydis that both the fragments of vaults and facades belong to the same first period of construction due to their interconnecting structure and the similar sizes of the bricks and mortar

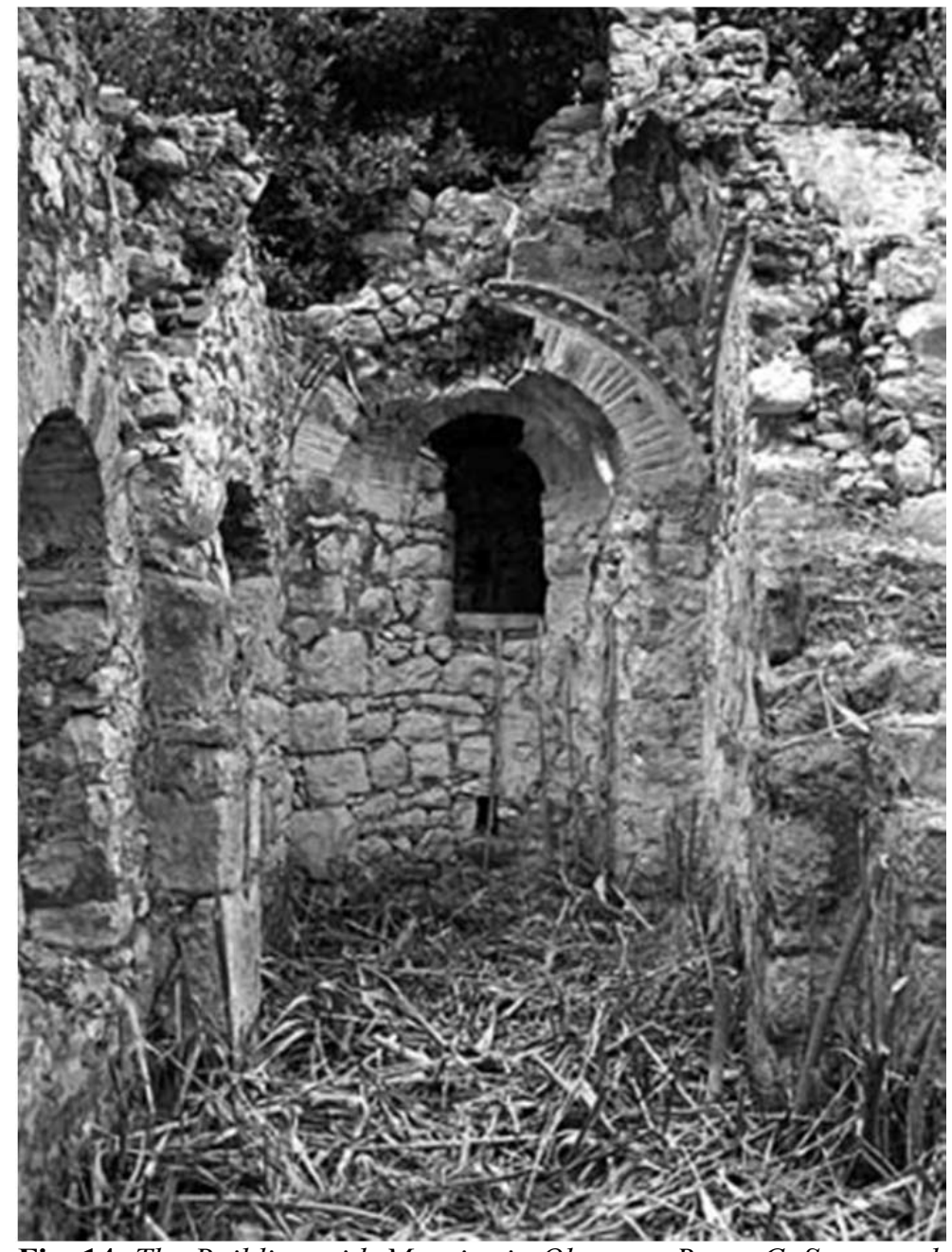

Fig. 14. The Building with Mosaics in Olympos, Room C, Saw- tooth band. Öztaşkın \& Öztaşkın 2012 (1), (Res. 3d) beds is convincing (Buchwald 1981, 304; Karydis 2011, 129). Further, at this juncture a remarkable detail draws our attention. If the saw-tooth bands which are traced in the northeast pier and perhaps also in the northwest piers indeed belong to the first period of the building, then we should reassess the common approach that buildings with saw-tooth ornament indicate only a period from the Middle or Late East Roman, particularly in Anatolia, considering also "the Building with Mosaics" in Olympos in Lycia, some arches of which are framed with saw-tooth brick bands and dated to about the $\mathrm{VI}^{\text {th }}$ century from the evidence obtained from extensive excavation work (for the Building with Mosaics see Öztaşkın \& Öztaşkın 2012a, 329-336; 2012b, 277-285) (Fig. 12-13). On the other hand, there still seems to be evidence that points to the restorations and functional fate of the church such as the presence of more than one layer of frescoes (Buchwald 1981, 309 fn. 9, 311), the remains of buttresses said to have been added after the risk from earthquake damage to the east and west side of the northeast pier and to the south side of the southwest pier, a number of graves and two coins dating from the XII ${ }^{\text {th }}$ century unearthed on the 
stairs of one of the buttresses. In addition to these traces, Passarelli argued that Makarios Khrysokephalos, the metropolitan of Philadelphia in the XIV ${ }^{\text {th }}$ century, was responsible for the restoration work carried out at the Church of St. Ioannes and delivered his Homily in the Feast of Orthodoxy at its inauguration (Talbot 1991a, 453. Since I could not find the cited publication, I can make no further comment at present). Although the total evidence is scarce upon which to base some specific ideas of the church's fate in later periods, it can at least be suggested that it continued to function for hundreds of years, perhaps until as late as the city's capture by the Ottomans.

\section{Concluding Remarks}

The continuing significance of Philadelphia through the ages has resulted in almost uninterrupted habitation to the present day and, in consequence, unfortunately, most of the remains have buried in the course of time beneath the modern city of Alaşehir. Consequently, the city does not exhibit its Hellenistic or Roman period structures, much less it Late Antique or East Roman. Nonetheless, indications are provided concerning the urban layout of Philadelphia, from the evidence provided by archaeological excavations, infrastructure works and the surviving remains.

All the evidence shows there were at least three primary sites -Gavurtepe Mound, Toptepe Hill and the walled precinct of the city- all of which have been exploited for various purposes for centuries by the inhabitants of Philadelphia. Here I wish to focus upon the varied utilization of these sites, in particular in the Late Antique and East Roman periods.

The excavations at Gavurtepe Mound, about $800 \mathrm{~m}$ to the east of the walled precinct of the city, have exposed so much evidence that indicates a dense pattern of settlement, inhabited especially through the Bronze Age, the small number of later finds do not provide enough evidence regarding subsequent settlement layout, as in the Hellenistic or Roman periods. On the other hand, at least according to the excavation reports, the Gavurtepe Mound appears to have been used as a cemetery from as early as the Late Hellenistic Period onwards, as R. Meriç has also pointed out. Apparently, a certain part of the cemetery sites in and near to the Gavurtepe Mound also contained burials which are said to be of Late Antique or East Roman date. Apart from these burials, no any evidence for any settlement has been identified and in consequence, one may suggest that Gavurtepe become one of the burial sites rather than a site of settlement in the Late Antique/ East Roman periods.

Having partly constituted the eastern part of the walled precinct of the city, Toptepe, provides much evidence from both the Roman and the later periods. Although at first sight neither part of the Toptepe displays any surviving monumental building, with the exception of the Roman Theatre and a small number of wall traces, the excavations conducted at the Theatre and the Theatre Temple have revealed many finds which enables us to suggest the site was also densely inhabited during Late Antiquity and in the East Roman period. Undoubtedly, it was its overlooking elevation providing a secure location which caused Toptepe Hill both to be included within the city walls and to maintain its feature of being a secure part of the city, perhaps into the last years of East Roman rule in Philadelphia.

The most useful evidence for the period in question comes from the walled precinct of the city. Despite the fact that the larger part of the Roman buildings have already disappeared, the infrastructure works having been conducted within the city walls in particular, have at times revealed a large quantity of Roman remains such as fragments of architectural carving from monumental buildings, sculptures, inscriptions and the like. That is to say, a certain part of the Roman settlement once stood upon Toptepe and the walled precinct. In a similar way, with the 
exception of several burial sites scattered around Gavurtepe and the west nekropolis, the bulk of the extant Late Antique and East Roman remains, namely the Church of St. Ioannes, the Galleries, the House with Mosaics, traces of a fortress and perhaps the Church of the Prophet Naum, some of the earliest stages of which may date back to the Roman period, are clustered in these same sections of the city. It is obvious that the urban settlement which at least dates back to the early Roman Period continued to develop with a certain number of renewals through Late Antiquity and the East Roman period, as was the case for most Antique cities in Anatolia. Unfortunately, today it is very difficult to have the chance of observing most of these remnants among the mass of modern buildings which have sprung up as a result of irregular urbanization, much less be able to investigate the transition processes involved in this settlement's development.

\section{REFERENCES}

Akıncı R. (1949). Eski Philadelphia Bugünkü Alaşehir. İzmir 1949.

Allom T. (1839). Constantinople and the Scenery of the Seven Churches of Asia Minor. London 1839.

Arslan M. (2007). Mithradates VI Eupator: Roma'nın Büyük Düşmanı. İstanbul 2007.

Arundell V. (1828). A Visit to the Seven Churches of Asia. London 1828.

Browning R. (1992). "A Fourteenth-Century Prose Version of the Odyssey". Homo Byzantinus: Papers in Honor of Alexander Kazhdan 46 (1992) 27-36.

Buchwald H. (1979). "Lascarid Architecture". JOB 28 (1979) 261-296.

Buchwald H. (1981). "The Church of St. John the Theologian in Alaşehir (Philadelphia)". JOB 30 (1981) 301-318.

Buchwald H. (1984). "Western Asia Minor as a Generator of Architectural Forms in the Byzantine Period, Provincial Back-wash or Dynamic Center of Production?". JOB 34 (1984) 199-234.

Buchwald H. (1986). "The Concept of Style in Byzantine Architecture". JOB 36 (1986) 303-316.

Burrel B. (2004). Neokoroi Greek Cities and Roman Emperors. Boston 2004.

Ceylan M. A. ( 2004). Şehir Coğrafyası Açısından Bir Araştırma: Alaşehir. İstanbul 2004.

Chandler R. (1971). Travels in Asia Minor (1764-1765). London 1971.

Choisy A. (1883). L'Art de Batir Chez les Byzantis. Paris 1883.

Curtius E. (1872). Philadelpheia, Nachtrag zu den Beiträgen zur Geschichte und Topographie Kleinasiens, aus den Abhandlungen der Königl. Berlin 1872.

Demirkent I. (2001). Ioannes Kinnamos'un Historiasl (1118-1176). Ankara 2001.

Demirkent I. (2006). Niketas Khoniates' in Historiast (1180-1195). İstanbul 2006.

Doğan C. (2002). Alaşehir Surları. Yayımlanmamış Lisans Tezi. Adnan Menderes Üniversitesi, FenEdebiyat Fakültesi, Arkeoloji ve Sanat Tarihi Anabilim Dalı, Klasik Arkeoloji Bölümü, Aydın 2002.

Drew-Bear T. \& Koder J. (1988). "Ein byzantinisches Kloster am Berg Tmolus”. JOB 38 (1988) 197-215.

Dunbabin M. D. (1999). Mosaics of the Greek and Roman World. Cambridge 1999.

Elliot C. (1838). Travels in the Great Empires of Austria, Russia and Turkey. Vol. 2. London 1838.

Erdoğan O. (2014). "On the History of Religions in Philadelphia in Lydia until the End of Late Antiquity". MJH IV/1 (2014) 171-179.

Ermiş Ü. M. (2011). "Son Yıllarda Ortaya Çıkarılan Mezar Odaları Işı̆ı̆ında İznik Nekropolleri”. TÜBAAR 14 (2011) 121-139.

Foss C. (1976) Byzantine and Turkish Sardis. Harvard 1976.

Foss C. (1979). "Late Byzantine Fortifications in Lydia". JOB 28 (1979) 297-320.

Foss C. (1982). "The Defences of Asia Minor Against the Turks". Greek Orthodox Theological Review 27 (1982) 145-205.

Foss C. (1991). "Philadelphia". ODB (Vol. 3) 1648. New York 1991.

Foss C. (2011). Bizans ve Türk Dönemlerinde Sardis. Ankara 2011. 
Foss C. \& Winfield D. (1986). Byzantine Fortifications: An Introduction. Pretoria 1986.

Gates M. (1995). “Archaeology in Turkey”. AJA 99/2 (1995) 207-255.

Hamilton W. (1842). Researches in Asia Minor, Pontus and Armenia. Vol. II. London 1842.

Hartley J. (1831). Researches in Greece and the Levant. London 1831.

Jonsson D. J. (2005). The Clash of Ideologies. Longwood 2005.

Karaca Z. (2008). İstanbul'da Tanzimat Öncesi Rum Ortodoks Kiliseleri. İstanbul 2008.

Karakaya E. (1987). "Sardes Hipojeleri (Mezar Odaları)". STAD 1 (1987) 18-27.

Karakaya E. (1995/1996). “Antik Philadelphia Nekropolü”. STAD 13 (1995/1996) 54-60.

Karydis N. D. (2011). Early Byzantine Vaulted Construction in Churches of the Western Coastal Plains and River Valleys of Asia Minor. Oxford 2011.

Karydis N. D. (2012). "A Monument of Early Byzantine Sardis: Architectural Analysis and Graphic Reconstruction of Building D". AnatStud 62 (2012) 115-139.

Kazhdan A. (1991). "Theme”. ODB (Vol. 3) 2034-2035. New York 1991.

Kelly C. (2004). Ruling the Later Roman Empire. Harvard 2004.

Kitto J. (1856). Cyclopaedia of Biblical Literature. Vol. 2. Edinburgh 1856.

Kongaz L. (1988). “İstanbul-Yeşilköy’de Bulunan Bir Bizans Hipojesi”. Sanat Tarihi Yılllğg 13 (1988) 117-129.

Koz S. (2013). Günümüz Türkçesiyle Evliya Çelebi Seyahatnamesi. Cilt 2. İstanbul 2013.

Laiou A. (2002). The Economic History of Byzantium from the Seventh Through the Fifteenth Century. Washington DC 2002.

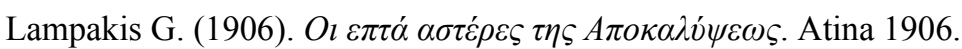

Macrides R. (2007). George Akropolites: The History. Oxford 2007.

Meinardus O. (1974). "The Christian Remains of the Seven Churches of the Apocalypse". The Biblical Archaeologist 37/3 (1974) 69-82.

Mellink M., Alkım U. et al. (1968). "Recent Archaeological Research in Turkey". AnatStud 18 (1968) 2143.

Mellink J. (1997). "Archaeology in Asia Minor". AJA 81/3 (1997) 289-321.

Mercangöz Z. (1985). Batı Anadolu’da Geç Dönem Bizans Mimarisi: Laskarisler Dönemi Mimarisi. Doktora Tezi. Hacettepe Üniversitesi, Sosyal Bilimler Enstitüsü, Sanat Tarihi Anabilim Dalı, İzmir 1985.

Mercangöz Z. (1990). “Bafa Gölü Kuzeyinde Kirselik’teki Manastır Kilisesi”. Ege Üniversitesi Edebiyat Fakültesi Arkeoloji ve Sanat Tarihi Dergisi V (1990) 117-138.

Meriç R. (1986). “1985 Yılı Alaşehir Kazı Çalışmaları”. KST VIII/2 (1986) 259-271.

Meriç R. (1987a). "1986 Yılı Alaşehir Kazısı Raporu”. KST IX/2 (1987) 243-244.

Meriç R. (1987b). "1986 Yılı İzmir ve Manisa İlleri Yüzey Araştırması”. AST V/1 (1987) 247-248.

Meriç R. (1988). "1987 Yılı Alaşehir Kazısı". KST X/1 (1988) 157-160.

Meriç R. (1989). "1988 Yılı Alaşehir Kazısı”. KST XI/1 (1989) 179-181.

Meriç R. (1990). "1988 Yılı Alaşehir Kazısı”. KST XI/1 (1990) 179-181.

Meriç R. (1992). “1990 Yılı Alaşehir Kazısı”. KST XIII/1 (1992) 227-229.

Meriç R. (1993). "1991 Yılı Alaşehir Kazısı”. KST XIV/2 (1993) 355-357.

Milner T. (1832). History of the Seven Churches. London 1832.

Mitchell S. (1993). Anatolia: Land, Men and Gods in Asia Minor. Vol I. Oxford 1993.

Nasturel P. Ş. (1984). "Recherches sur le Testament de Maxime de Skoteine (1247)". Philadelphie et autres Etudes 4 (1984) 69-100.

Newbold C. (1852). "The Seven Churches of Asia". Journal of the Royal Asiatic Society of Great Britain and Ireland 13 (1852) 86-94.

Onur F. (2013). Ioannes Lydos ve Peri Arkhon. İstanbul 2013.

Öztaşkın M. \& Öztaşkın G. K. (2012a). “Antalya-Olympos Mozaikli Yapı”. Uluslararası Genç Bilimciler 
Buluşması-I: Anadolu Akdenizi Sempozyum Bildirileri (2012) 329-346.

Öztaşkın M. \& Öztaşkın G. K. (2012b). "The Building with Mosaics in Olympos: A Comparative Evaluation of Finds and Building Construction". Eds. Beate Böhlendorf-Arslan \& Alessandra Ricci. Byzantine Small Finds in Archaeological Contexts. BYZAS 15 (2012) 277-287.

Pekak M. S. (2009). “Osmanlı İmparatorluğu Döneminde Gayrimüslim Vatandaşların İmar Faaliyetleri ve Mustafapaşa (Sinasos)”. Bilig 51 (2009) 171-204.

Strabon (= Strabon, Geographika) Kullanılan Metin ve Çeviri: Strabon: Antik Anadolu Coğrafyası (Geographika: Kitap XIII). Çev. A. Pekman. İstanbul 2009.

Pralong A. (1984). "Les Remparts de Philadelphie". Tire a part de Philadelphie et autres Etudes (1984) 101-126.

Ramsay W. M. (1904). The Letters to the Seven Churches of Asia. London 1904.

Ridley R. T. (1990). Zosimus: New History. Canberra, Australia 1990.

Sinkewicz R. E. (1994). Theoleptos of Philadelphia: The Monastic Discourses. Wetteren 1994.

Strzygowski J. (1903). Kleinasien: Ein Neuland der Kunstgeschichte. Leipzig 1903.

Talbot A. M. (1991a). "Makarios Chrysokephalos". ODB (Vol. 2). New York.

Talbot A. M. (1991b). “Theoleptos”. ODB (Vol. 3). New York.

Texier C. (2002). Küçük Asya. Cilt 2. Çev. Ali Suat. Ankara 2002.

Thomas J. \& Hero A. C. (2000). Byzantine Monastic Foundation Documents. Washington 2000.

Thonemann P. (2011). The Meander Valley: A Historical Geography from Antiquity to Byzantium. Cambridge 2011.

Tok E. (2010). Manisa Yakınlarında Bir Ortaçă̆ Kalesi: Yoğurtçu Kale. Manisa 2011.

Tok E. (2011). "A New Mosaic Unearthed by an Illicit Excavation in Alaşehir (Philadelphia)". JMR 4 (2011) 51-66.

Turtledove H. (1982). The Chronicle of Theophanes. Philadelphia 1982.

Umar B. (1996). Anna Komnena: Alexiad. İstanbul 1996.

Umar B. (2008). Doukas, Tarih: Anadolu ve Rumeli. İstanbul 2008.

Vryonis S. (1971). The Decline of Medieval Hellenism in Asia Minor and the Process of Islamization from the Eleventh Through the Fifteenth Century. California 1971.

Zanten D. T. V. (1975). "The City Walls". A Survey of Sardis and the Major Monuments Outside the City Walls (1975) 35- 53. London. 